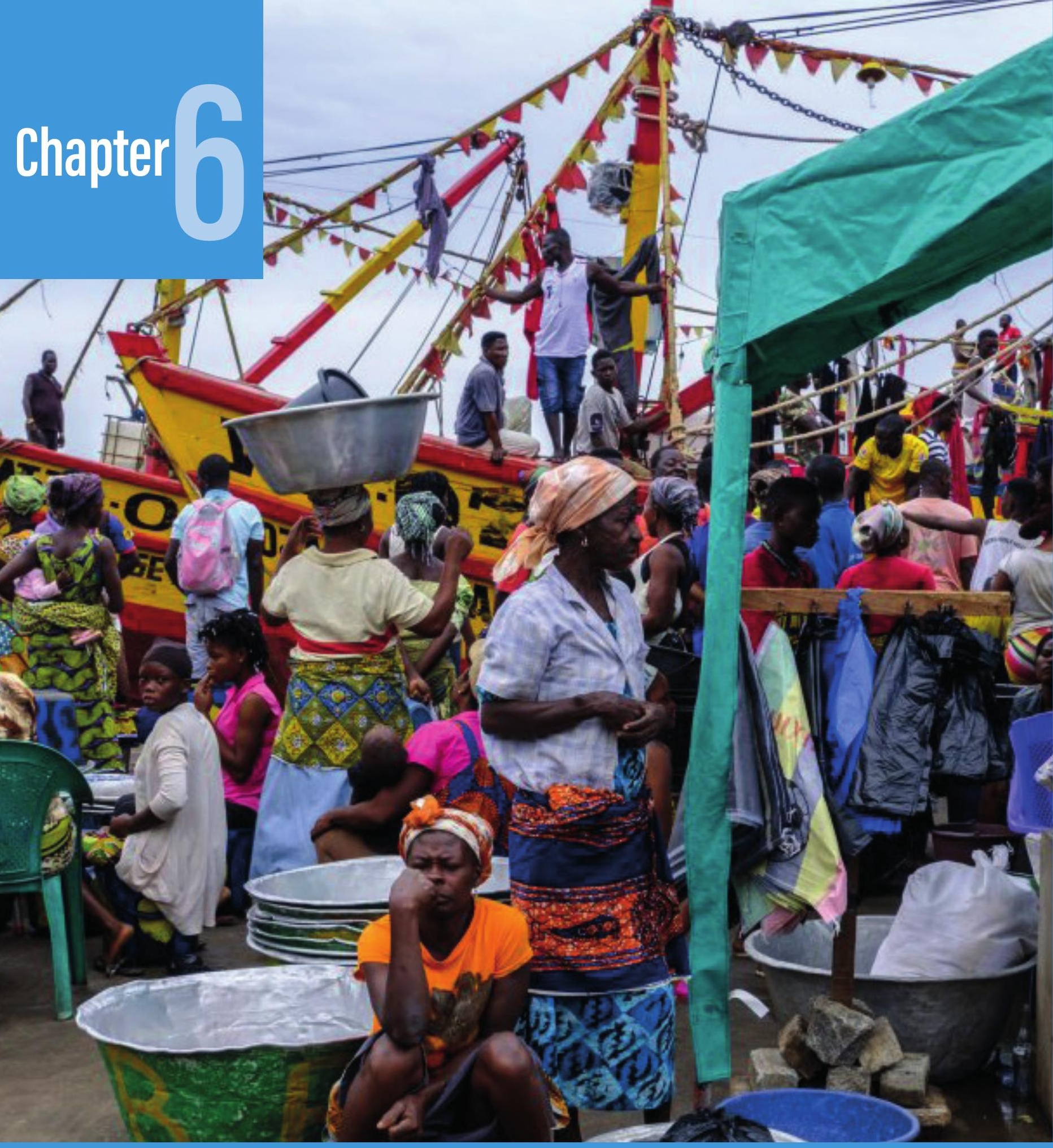

\title{
Regional Integration in Southern Africa
}

Busani Moyo, Marko Kwaramba, and Mamello Nchake 


\section{Introduction}

Southern Africa has many regional economic communities (RECs), which are experiencing varied success in promoting trade. These include the Southern African Development Community (SADC), Common Market for Eastern and Southern Africa (COMESA), East African Community (EAC), and Southern African Customs Union, (SACU), with many countries having overlapping membership in different regional communities. The Southern African Development Coordinating Conference (SADCC) - the precursor to SADC - was established in 1980 with the specific aim of lessening dependence on apartheid-era South Africa. In 1992, the Southern African Development Community Treaty was signed, transforming SADCC into SADC. SADC graduated to become a free trade area in 2008 but has not yet transitioned to the next regional integration stage for various reasons, including lack of political will, proliferation of regional groupings, and lack of experienced human resources and funding. In addition, regional indicators show that SADC countries are at different levels of trade integration. South Africa is the predominant economy in SADC - the largest in terms of gross domestic product (GDP), the most diversified, and the overall best-performing country in terms of integration, scoring highest on trade, financial, and macroeconomic integration (especially among SACU countries), and is also the only country that scores above average on all five regional integration dimensions (AUC 2016).

Southern Africa is failing to diversify away from primary commodities. SADC mainly trades commodities, especially primary products. In this chapter, we focus on trade in agricultural products. Agriculture is a key sector in most Southern African economies and plays a crucial role in trade and regional integration. Agriculture contributes 15 percent of total GDP in Africa, however, its contribution ranges from less than 3 percent in Botswana and South Africa to more than 30 percent in Malawi (World Bank 2016). Trade of agricultural products is low (Bouët and Odjo 2019). There is heterogeneity in agricultural exports across SADC countries, with South Africa dominating exports to SADC countries. SADC countries export similar products (tobacco, maize, sugar) - which may explain why intraregional trade is low. The top 10 intra-SADC exported products include sugar, live animals, maize, and tobacco, with the most traded products by value being maize from South Africa, followed by sugar from Eswatini, and cattle from Namibia. Most RECs in Southern Africa (SADC, SACU, COMESA, and EAC) have a comparative advantage in vegetable products, though for SADC it has been declining. Agricultural trade at the intensive margin ${ }^{1}$ has been declining for Zambia, Malawi, Zimbabwe, and Mozambique; however, for South Africa, the intensive margin index of all products has been increasing. The ability to trade new agricultural products (extensive margin) varies across SADC countries, with Malawi, Democratic Republic of the Congo (DRC), Lesotho, and Zimbabwe showing a declining trend.

South Africa dominates participation in various commodity value chains among SADC member states. Most of the intermediate goods exported and imported within the SADC region are from South Africa, in terms of averaged values for the period 2003-2017. This trend is also observed by Black et al. (2019), who find that South Africa is the main source of foreign value-added exports within the SADC region. Of the SADC countries, Zimbabwe, Tanzania, South Africa, and Zambia produce many agricultural goods, including tea, tobacco, maize, and sugar, but despite this advantage, SADC countries, with the exception of South Africa, have failed to accelerate industrialization through processing and value addition. Onoja, Achike, and Ajibade (2017) find that many SADC countries risk being trapped in producing low-skill, low-value products and services, and struggling to obtain a significant value-added share in global trade.

1 Economists describe variations in trade flows along two different margins. If trade changes in existing trade flows (increase, decrease, or extinction), this is the intensive margin. If trade changes because of the introduction of a new product, export to a new destination, or product diversification with an existing partner, this is the extensive margin. 
Intra-SADC agricultural trade and participation in both regional and global value chains is inhibited by high tariff and nontariff barriers. Bouët et al. (2017) show that Africa, in general, is the least open continent in the world. Its import duty on all merchandise is 9.7 percent; protection is particularly high for the agricultural sector, with tariff levels of about 19.6 percent, compared to 8.3 percent imposed on non-agricultural sectors. At the country level, five SADC countries - Malawi, Seychelles, Tanzania, Zambia, and Zimbabwe - have average agricultural duties above the regional (SADC) average, which inhibits trade in agricultural goods. Nontariff barriers affecting intra-SADC trade include trade licensing, quotas and bans, price controls, competition policies, rules of origin, technical barriers to trade, and poor infrastructure. Kalaba et al. (2016) find that nontariff barriers have been increasing over time, inhibiting intra-SADC agricultural trade. Fall and Gasealahwe (2017), Novy (2012), and Arvis et al. (2016) argue that poor infrastructure, policy factors, and nontariff barriers contribute to the high costs of trade in SADC. Regional infrastructure integration is limited among SADC countries, and the low quality of infrastructure in the region adds to intraregional trade friction. Customs inefficiency is generally high, but these costs of cross-border trade vary widely across countries in the region. Tanzania and the DRC are the worst performing countries in terms of customs efficiency.

This chapter examines agricultural trade integration in Southern Africa, focusing on SADC. We begin with a brief description of the evolution of SADC, followed by a detailed description and analysis of SADC agricultural trade flows and patterns and of possible drivers of the observed trade patterns. The next section discusses the evolution of regional trade agreements in Southern Africa with particular focus on SADC, and the following sections discuss trade integration in SADC, focusing on agricultural trade and possible explanations for the observed trade patterns and flows.

\section{Evolution of regional trading blocs in Southern Africa}

Southern African regional trading blocs have evolved over time. We focus in this chapter on SADC, with little reference to SACU and COMESA. The present and future of regionalism in Southern Africa can be, to some extent, approached and understood in the context of the past (Hwang 2007).

\section{Evolution of trade agreements}

Regional integration in Southern Africa dates back as far as 1910, when the Southern African Customs Union (SACU) was formed by South Africa, Botswana, Swaziland (Eswatini), and Lesotho before being joined by Namibia in 1990. In 1980, in Lusaka, nine states - namely Angola, Botswana, Eswatini, Lesotho, Malawi, Mozambique, Tanzania, Zambia, and Zimbabwe - formed the Southern Africa Development Coordination Conference (SADCC). SADCC was formed with four principal objectives, including the reduction of member states' dependence particularly, but not only, on apartheid-era South Africa (du Plessis, Smit, and McCarthy 2000). The Common Market for East and Southern Africa (COMESA) was formed in 1994, replacing a preferential trade area (PTA) that had existed since 1981. COMESA became a free trade area in 2000. The problem of overlapping membership, which is widespread in the continent, is also common in Southern Africa.

The evolution of SADC began with the transformation of SADCC into a development community the Southern African Development Community (SADC) - in 1992, in which member states agreed 
and committed to shifting the region from economic cooperation toward economic integration. The SADC Protocol on Trade, which was passed on August 24, 1996, ${ }^{2}$ but came into force in 2000, resulted in progressive elimination of trade barriers and thereby the establishment of a SADC free trade area (SADC-FTA) by 2008. The SADC integration agenda involved promotion of agriculture. The Declaration on Agriculture and Food Security of May 15, 2004, set out SADC member states' commitment to enhancing agriculture as a means of improving access to food for people in the region.

New member countries have expanded SADC over the years, from the seven Frontline States in 1975, to a nine-member coalition in 1980. Today, SADC has 16 member states: Angola, Botswana, Eswatini, DRC, Comoros (joined in 2017), Lesotho, Madagascar, Malawi, Mauritius, Mozambique, Namibia, Seychelles, South Africa, Tanzania, Zambia, and Zimbabwe.

SADC, however, has failed to meet the regional integration milestones it set out. The initial Regional Indicative Strategic Development Plan (RISDP) (2005-2020) was formulated in March 2001 and was adopted and approved by the SADC Summit in August 2003, with the objective of deepening regional integration. The RISDP outlines a series of milestones to be achieved within the context of the SADC Common Agenda, for which it seems largely off-track and which may be superseded by Africa-wide initiatives such as the African Continental Free Trade Agreement (AfCFTA). ${ }^{3}$ The targets and timeframes for the integration milestones as endorsed by SADC include formation of a free trade area by 2008; a customs union by 2010; a common market by 2015; a monetary union by 2016; and, finally, adopting a single currency and becoming an economic union by 2018. To date, SADC has only achieved the first of these milestones; the SADC-FTA was officially launched on August 28, 2008. Maximum tariff liberalization was only attained in January 2012, when the tariff phase-down process for sensitive products was completed (Behar and Edward 2011). The revised SADC Regional Indicative Strategic Development Plan (RISDP 2015-2020) marks industrial development and market integration as a top priority, with the overall goal of facilitating competitive and diversified industrial development for deeper regional integration and poverty eradication.

\section{Constraints facing Southern African regional trade agreements}

A number of challenges have prevented SADC from moving beyond the free-trade-area stage to the next regional integration stage. To become a customs union, the region must establish a single common external tariff, which is challenging in SADC given the many different individual tariff policies that must converge into a single and uniform tariff regime. Overlapping membership across various regional groupings as well as differences in development interests affect the transition to a common market. All SADC countries, with the exception of Mozambique, belong to more than one regional trading bloc. In addition, experienced human resources (skills) are in short supply. Also in short supply is the investment needed to facilitate cooperation and harmonization in the banking sector, a critical prerequisite for forming a monetary union. This problem is compounded by the prevailing weak monetary and fiscal variables in many member states. For the period 2003 to 2018, inflation levels in 8 of the 16 countries were above the region's convergence target of 7 percent, with public sector debt-to-GDP ratios very high and above the recommended 60 percent threshold in countries including Mauritius (63 percent), Mozambique (100 percent), and Zimbabwe (66 percent) (AfDB 2019). Botswana is the only country with foreign reserves sufficient to cover six months of imports. In addition, the harmonization of the SADC banking sector has been affected

2 Available on SADC website: https://www.sadc.int, accessed on February 18, 2020.

3 The Agreement for establishing the African Continental Free Trade Agreement (AfCFTA) came into effect on May 30, 2019, for the 24 countries that had deposited their instruments of ratification. 
by asymmetric external shocks and challenges in harmonizing different country regulations governing the sector.

The African Union Commission (AUC), African Development Bank (AfDB), and United Nations Economic Commission for Africa (UNECA) highlight five regional integration dimensions: trade integration, regional infrastructure, free movement of people, financial and macroeconomic integration, and productive integration. ${ }^{4}$ In terms of individual countries, South Africa is the overall best-performing country on these five dimensions, has the highest scores on trade and on financial and macroeconomic integration, and is the only country that performs above average on all five dimensions. The poorest performing country across the five indicators is Angola. In terms of the RECs, SACU has the highest overall score compared to SADC and COMESA (see Figure 6.1).

Figure 6.1 Integration scores for Southern Africa, 2016

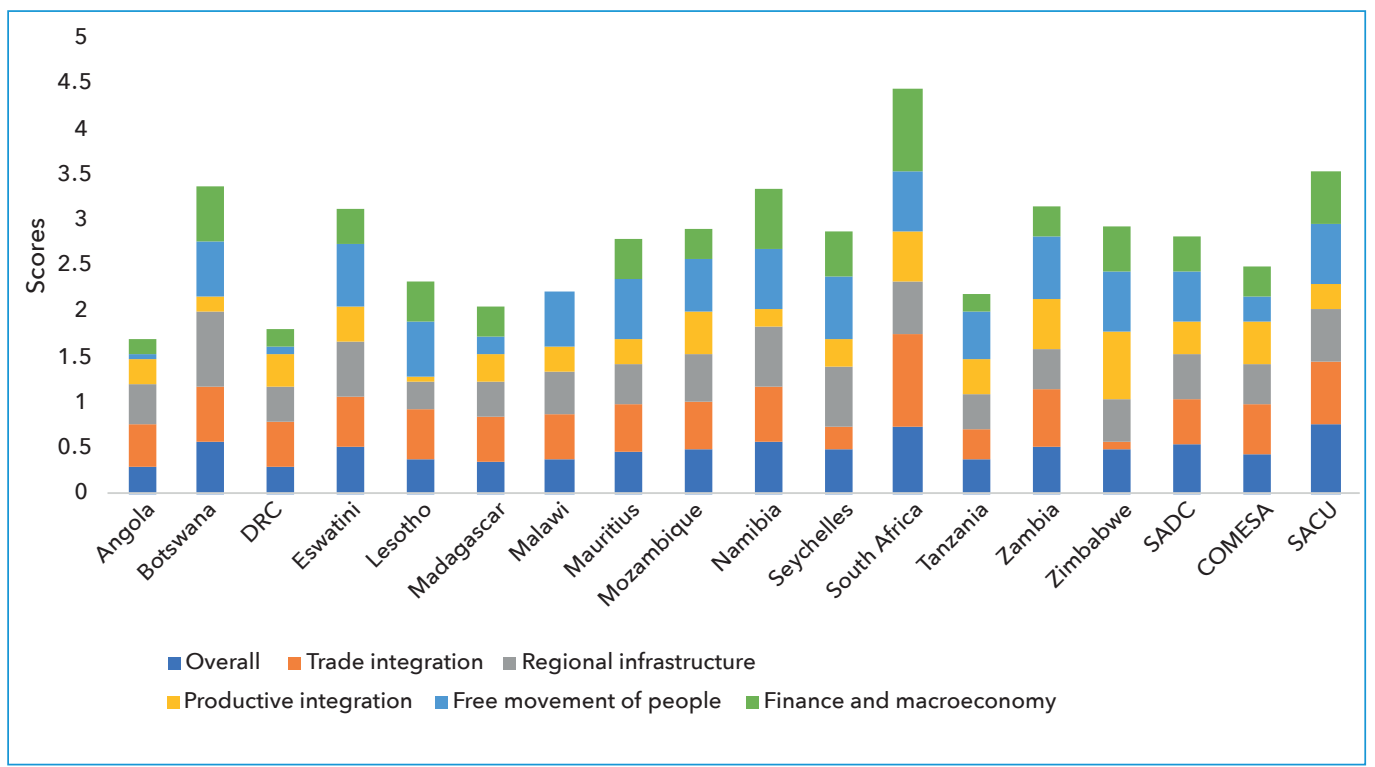

Source: AUC (2016).

Note: Scores range from a low of zero to a high of 1 . The higher the score, the greater the integration.

\section{Trade integration in Southern Africa}

This section discusses trade integration in Southern Africa, with a specific focus on SADC, agricultural trade, and regional value chains. Agriculture is a key sector in African economies and plays a crucial role in trade and regional integration. On average, agriculture's contribution to GDP is high at 15 percent of total GDP (FAO 2016). However, trade of agricultural products continues to be low. This means that Africa has a huge scope to strengthen agro-industries and agro-processing and to promote intraregional trade through regional value chains. The Malabo Declaration of 2014 clearly articulates the need to boost agricultural productivity and intra-African trade in agricultural commodities.

4 Productive integration is measured using the share of regional intermediate goods exported and imported in total intraregional trade as well as the merchandise trade complementarity index. Trade in intermediate goods is more important for productivity, improving resilience to shocks, and diversification. 


\section{Profile of agricultural products exported by the SADC regional members}

Africa's resolution to triple intra-African trade in agriculture commodities and services ${ }^{5}$ by the year 2025 is facing many obstacles. This is because of the continent's failure to diversify away from primary commodities, coupled with insufficient trade infrastructure and the high cost of trade, as well as continued prevalence of nontariff measures (NTMs) (Bouët et al. 2008). Kalaba et al. (2016) find that most of the NTMs are applied on fruits, meat, dairy, vegetables, and cereal products - key products traded by the SADC members. Recent literature shows that Africa's agricultural trade has increased over time and that intraregional trade is increasing though still below potential (Bouët and Odjo 2019). The share of agricultural products exported within SADC by member countries is low compared to SADC exports to other regions. Intraregional trade in SADC of agricultural commodities is also far less than in other regions.

Figure 6.2A shows that the share of Southern African agricultural exports in total world agricultural exports has remained almost constant across the region's four RECs. All RECs show a drop in trade during the 2007/2008 economic crisis. The trend is also reflected in the share of intra-REC agricultural exports (Figure 6.2B), where EAC's upward trend and the downward trend for COMESA are amplified. Intra-REC agricultural exports increased after the 2007/2008 crisis and then started to decline after 2012, with the exception of EAC which showed a persistent upward trend, and of COMESA with its clear downward trend. Of the total agricultural exports, only 30 percent are exported within SADC while the rest go to other countries (Figure 6.2B). A similar trend is shown by the intraregional trade intensity index (Figure $6.2 \mathrm{C}$ ) and the regional trade introversion index. ${ }^{6}$ Figure 6.2D shows that all four RECs are introverted, but introversion is decreasing for COMESA while increasing for EAC. SADC and SACU show a higher and constant degree of introversion that is, the level of regional trade as a share of total trade is relatively high.

The above results support the findings of the existing literature. Data from ITC TradeMap (2017) show that intra-African agricultural exports account for only 26 percent of Africa's global agricultural exports, as only a few products are traded among countries within the same RECs. Sandrey et al. (2018) show that intra-SADC agricultural exports represent 47 percent of the total agricultural trade, with South Africa and Zimbabwe the largest exporters. In general, intra-African trade is minimal, and SADC is no exception. Some of the trade-limiting factors identified by Sandrey et al. (2018) include a mismatch in supply and demand; supply-side bottlenecks such as input shortages, obsolete technology, and lack of knowledge transfer; inefficient infrastructure in transportation, communications, electricity, and warehousing facilities; and trade barriers and nontrade barriers.

5 This was adopted at an Africa Union high-level meeting through the Malabo Declaration on Accelerated Agriculture Growth and Transmission for Shared Prosperity and Improved Livelihoods (AUC 2014)

6 See Bouët and Odjo (2019) for more detailed explanation of the index. The regional trade introversion index addresses some of the shortcomings that arise from using the share of intraregional trade as a measure of integration. The introversion index is based on modifications of both intra- and extraregional trade intensity indices, and compares a region's share in trade with the rest of the world. It is the ratio of the difference between intra- and extraregional intensity indexes to their summation. A positive figure shows that the region is more introverted than extraverted. 
Figure 6.2 Trade indicators for agricultural exports

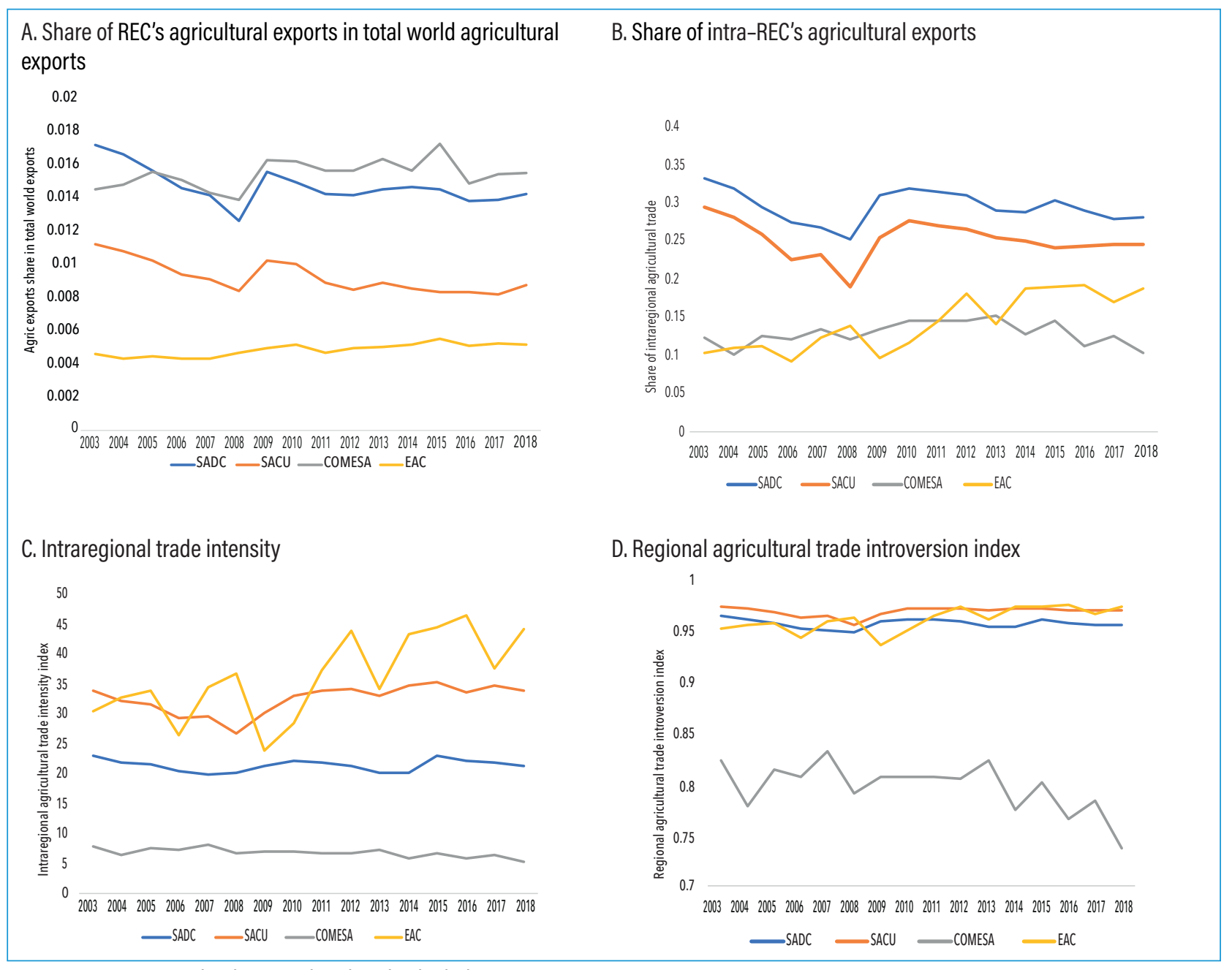

Source: 2020 AATM database and authors' calculation.

However, there is heterogeneity in agricultural exports across SADC countries. South Africa dominates other countries in exporting to SADC (Figure 6.3), accounting for over 60 percent of intra-SADC exports in 2018, up from 50 percent in 2005 (South Africa's GDP is larger than the GDP of the rest of SADC together). Oluwatabo et al. (2014) find that the SADC free trade agreement (SADC-FTA) has a net trade-creating effect on South African agricultural trade and has increased intra-SADC trade. Despite predominance in agricultural products, South Africa exports a highly diversified range of products, from agricultural products to high-value manufactured goods that are much needed by other SADC countries. Some SADC countries, including Botswana, Namibia, Zambia, and Zimbabwe, have decreased their intra-SADC agricultural exports over time. However, Eswatini, Mauritius, and Tanzania have increased their trade share within the region, though it remains below 7 percent. 
Figure 6.3 Intra-SADC agricultural export share, by country

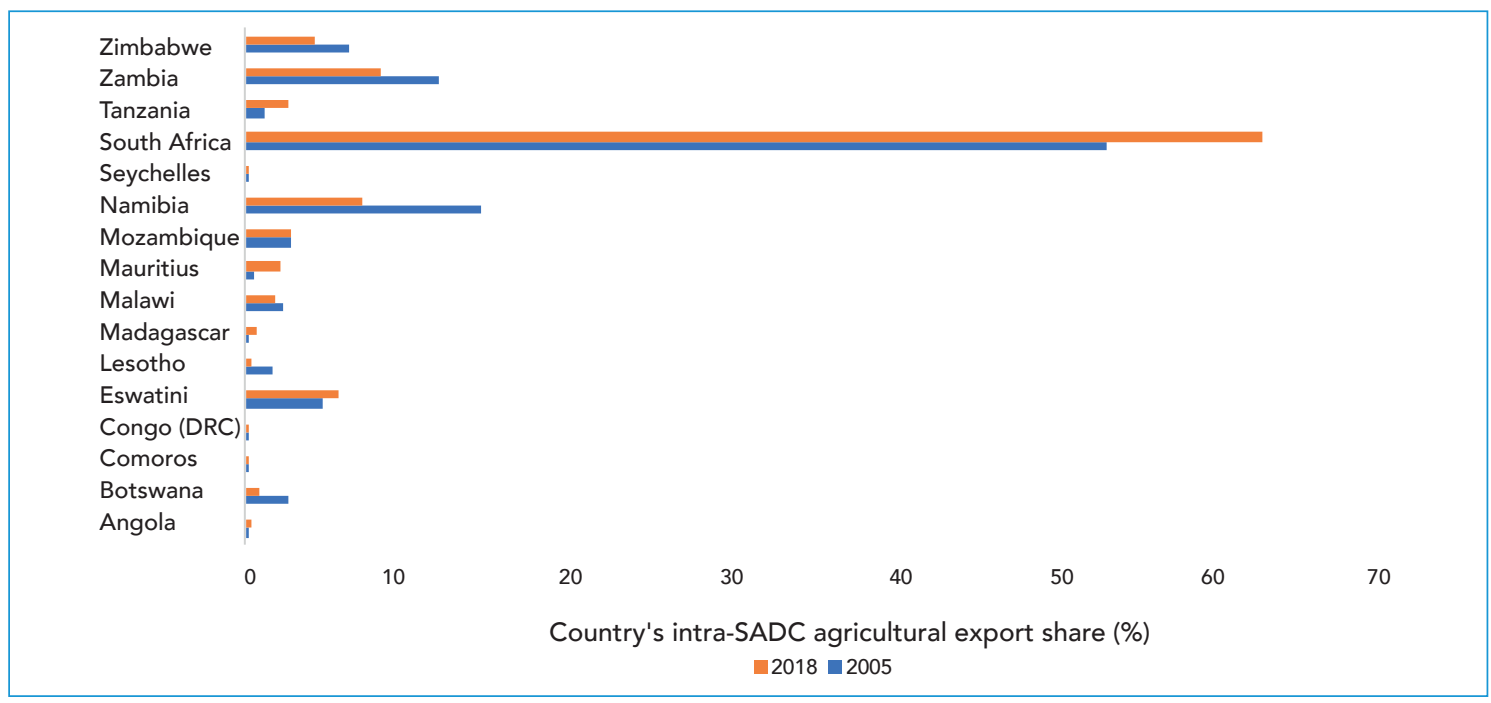

Source: 2020 AATM database and authors' calculation.

Intra-SADC agricultural imports are also dominated by South Africa (Figure 6.4). But at less than 25 percent, South Africa's share of imports is far lower than its export share.

Figure 6.4 Intra-SADC agriculture import share, by country

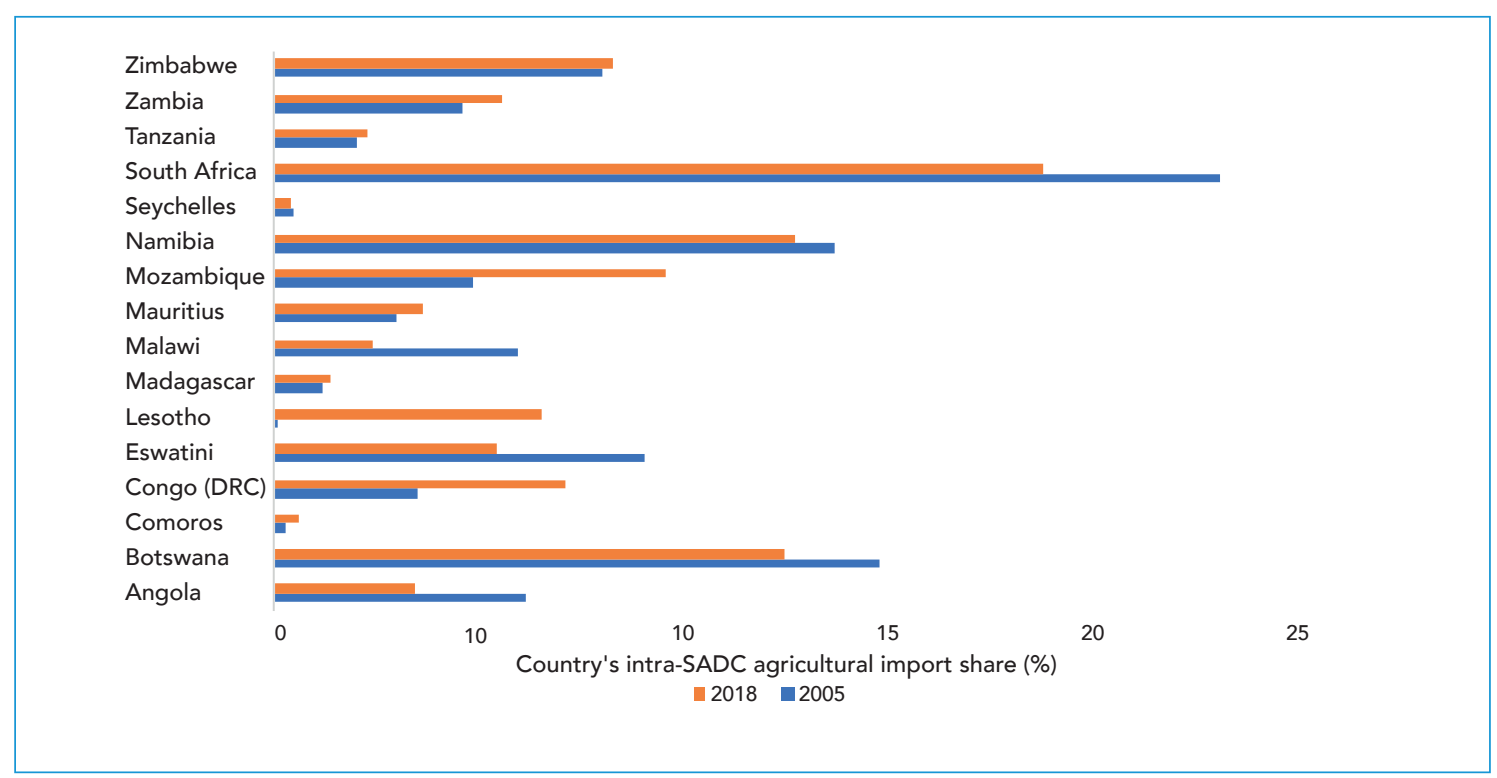

Source: 2020 AATM database and authors' calculation.

SADC countries export similar products (tobacco, maize, sugar, live animals), which may explain why intraregional trade is low. Table 6.1 shows the top three products exported within SADC by each SADC country. The products range from live animals to maize to tobacco. The highest intraSADC traded products by value (average for 2016-2018) are maize from South Africa, followed by sugar from Eswatini and cattle from Namibia. South Africa generally dominates agricultural exports by value across regions (average for 2016-2018), be it to SADC (maize), Africa (maize), or the world (edible fruits). Existing literature shows that intraregional trade in maize has been stimulated by the implementation of the SADC-FTA agreement and has benefited South Africa. Despite maize 
dominance by South Africa, Mmaduabuchukwu (2013) confirms Southern Africa's fifth position among major exporters of maize in the world. The arable land and climatic endowment suggest SADC has potential to produce and export more maize.

Table 6.1 Top agricultural products exported within SADC

\begin{tabular}{|c|c|}
\hline Country & Top Products Exported within SADC \\
\hline Angola & $\begin{array}{l}\text { Sugars: sucrose, chemically pure; Beer: made from malt; Waters: including } \\
\text { mineral and aerated }\end{array}$ \\
\hline Botswana & $\begin{array}{l}\text { Meat: of bovine animals; Vegetables, leguminous: beans of the species; } \\
\text { Cigarettes: containing tobacco }\end{array}$ \\
\hline Congo (DRC) & $\begin{array}{l}\text { Cattle: live, other than pure-bred breeding animals; Coffee: not roasted or } \\
\text { decaffeinated: Cereals: maize (corn) }\end{array}$ \\
\hline Comoros & $\begin{array}{l}\text { Spices: cloves (whole fruit, cloves and stems); Meat preparations: of swine, } \\
\text { hams, and cuts; Sugar confectionery }\end{array}$ \\
\hline Lesotho & $\begin{array}{l}\text { Bran, sharps and other residues: of maize (corn); Wool: (other than } \\
\text { shorn); Hair: fine animal hair, not carded or combed, other than of kashmir } \\
\text { (cashmere) goats }\end{array}$ \\
\hline Madagascar & $\begin{array}{l}\text { Vegetables, leguminous: broad beans; Spices: vanilla, crushed or ground; } \\
\text { Cotton: not carded or combed }\end{array}$ \\
\hline Mozambique & $\begin{array}{l}\text { Fruit, edible: bananas, other than plantains; Bran, sharps and other residues: } \\
\text { of wheat; Tobacco }\end{array}$ \\
\hline Mauritius & $\begin{array}{l}\text { Cereals: maize (corn); Vegetable oils: soya-bean oil and its fractions; } \\
\text { Vegetable oils: palm oil and its fractions }\end{array}$ \\
\hline Malawi & $\begin{array}{l}\text { Tea, black: (fermented) and partly fermented tea; Groundnuts: other than } \\
\text { seed; Sugars: sucrose }\end{array}$ \\
\hline Namibia & $\begin{array}{l}\text { Cattle: live, pure-bred breeding animals; Sheep: live; Meat: of sheep, } \\
\text { carcasses }\end{array}$ \\
\hline Eswatini & $\begin{array}{l}\text { Sugars: cane sugar, raw, in solid form; Sugars: sucrose, chemically pure, } \\
\text { in solid form }\end{array}$ \\
\hline Seychelles & $\begin{array}{l}\text { Animal products: of fish or crustaceans; Fruit, edible: bananas, other than } \\
\text { plantains; Food preparations }\end{array}$ \\
\hline Tanzania & Tea; black; Wheat or meslin flour; Waters: other than mineral and aerated \\
\hline South Africa & $\begin{array}{l}\text { Cereals: maize (corn), other than seed; Vegetable oils: soya-bean oil and its } \\
\text { fractions; Sugars: sucrose, chemically pure }\end{array}$ \\
\hline Zambia & $\begin{array}{l}\text { Cereals: maize (corn), other than seed; Oil-cake and other solid residues; } \\
\text { Tobacco: partly or wholly stemmed or stripped }\end{array}$ \\
\hline Zimbabwe & $\begin{array}{l}\text { Tea: black (fermented) and partly fermented; Sugars: cane sugar, raw, in solid } \\
\text { form; Tobacco; Cotton: not carded or combed }\end{array}$ \\
\hline
\end{tabular}

Source: 2020 AATM database. 


\section{International competitiveness and market diversification}

For trade intensification, countries need to show a comparative advantage. Figure 6.5 shows that all four RECs have a comparative advantage in vegetable products, with a revealed comparative advantage (RCA) greater than 1. However, SADC shows a consistent, declining, and low RCA for vegetable products. Most RECs do not have a comparative advantage in animal products, with the exception of EAC, which showed a spike only in 2017. The comparative advantage for animal products declined during the $2007 / 2008$ crisis, followed by a recovery and another decline from 2012 to 2014. The figure shows that RCA started to decline again in 2016, possibly because of drought conditions that prevailed during that time.

Figure 6.5 REC revealed comparative advantage, agricultural products

Revealed comparative advantage-vegetables

Revealed comparative advantage- animal products

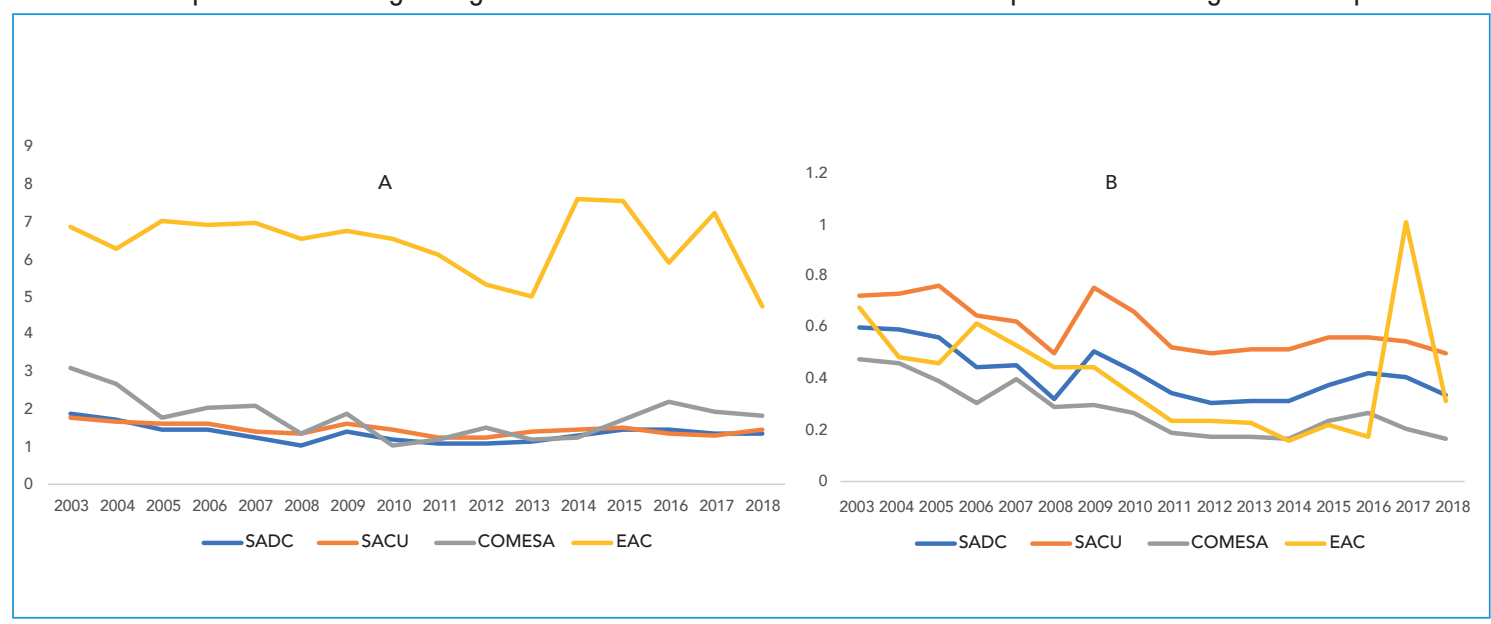

Source: 2020 AATM database.

SADC countries show greater heterogeneity in comparative advantage. The data show that Botswana, Mauritius, and Namibia have a comparative advantage in animal products, while eight SADC countries, including Comoros, Madagascar, Mozambique, Mauritius and Malawi, show consistent $\mathrm{RCA}$ in vegetable products.

Table 6.2 shows that despite low comparative advantages in animal products, some countries show growth in this comparative advantage over the years, including Angola, Zambia, and Tanzania. RCA for animal products decreased in 10 of the 16 SADC countries between 2013 and 2018. RCA in vegetables is low, but 8 of the 16 SADC countries show marginal increases in comparative advantage. 
Table 6.2 SADC countries' revealed comparative advantage (RCA) for exports, 2013 and 2018

\begin{tabular}{l|rrr|rrr}
\hline & Animal products & & & \multicolumn{3}{l}{ Vegetables products } \\
\hline & 2003 & 2013 & 2018 & 2003 & 2013 & 2018 \\
\hline Angola & 0.01 & 0.00 & 0.01 & 0.01 & 0.00 & 0.01 \\
Botswana & 1.32 & 1.09 & 0.95 & 0.07 & 0.03 & 0.06 \\
Congo (DRC) & 0.11 & 0.00 & 0.00 & 0.49 & 0.14 & 0.11 \\
Comoros & 0.04 & 0.06 & 0.07 & 32.33 & 22.31 & 21.94 \\
Lesotho & 0.06 & 0.12 & 0.07 & 0.53 & 0.99 & 0.37 \\
Madagascar & 0.07 & 0.04 & 0.04 & 11.17 & 5.62 & 12.50 \\
Mozambique & 0.14 & 0.01 & 0.01 & 1.18 & 1.39 & 1.46 \\
Mauritius & 0.98 & 1.21 & 1.50 & 0.43 & 0.68 & 1.30 \\
Malawi & 0.01 & 0.30 & 0.04 & 5.74 & 5.39 & 5.94 \\
Namibia & 5.74 & 3.44 & 2.84 & 0.86 & 0.59 & 0.42 \\
Eswatini & 0.67 & 0.25 & 0.13 & 0.72 & 0.57 & 0.39 \\
Seychelles & 0.02 & 0.16 & 0.15 & 0.09 & 0.46 & 0.82 \\
Tanzania & 0.68 & 0.24 & 0.32 & 6.88 & 5.00 & 4.77 \\
South Africa & 0.53 & 0.34 & 0.34 & 1.99 & 1.56 & 1.64 \\
Zambia & 0.47 & 0.07 & 0.14 & 2.30 & 0.76 & 0.34 \\
Zimbabwe & 0.55 & 0.14 & 0.05 & 3.99 & 1.26 & 1.10 \\
\hline
\end{tabular}

Source: 2020 AATM database.

Note: Green shading indicates countries with RCA.

Diversification is critical to facilitate regional integration. African trade is less diversified both in terms of products and markets compared to the rest of the world (Bouët et al. 2017). Furthermore, most African countries have been found to export a smaller number of agricultural products compared to non-African countries. Most SADC countries appear less diversified based on the number of agricultural products exported across countries. We use Hummels and Klenow (2005) measures of extensive and intensive margins to capture diversification. The extensive margin involves trading new products that were not previously traded to either existing trading partners or to new trading partners; the intensive margin is the trading of already existing products to already existing trading partners. We report the results at product level - the aggregated trade values or the number of products that are newly traded. The results show that South Africa, Tanzania, and Zambia's, intensive margin of all products has been increasing over the two periods (using averages for 2005-2007 and 2016-2018) while it declined for Angola, Eswatini, Mauritius, and Zambia (Figure 6.6). For agricultural products, Tanzania, Madagascar, and Zimbabwe have an increasing intensive margin, while it has decreased for South Africa, Zambia, and Mauritius.

The ability of SADC countries to trade new agricultural products varies. Results show an increase in the number of agricultural products (extensive margin) over the two periods (using averages for 2005-2007 and 2016-2018) for Angola, Lesotho, Mauritius, Mozambique, and Zambia. In contrast, Madagascar, Malawi, Seychelles, and Zimbabwe all show a decrease in the extensive margin (Figure 6.7). For both periods, South Africa has the highest level of trade at both the intensive and extensive margins for both agricultural products and all products. 
Figure 6.6 Hummels and Klenow intensive margins

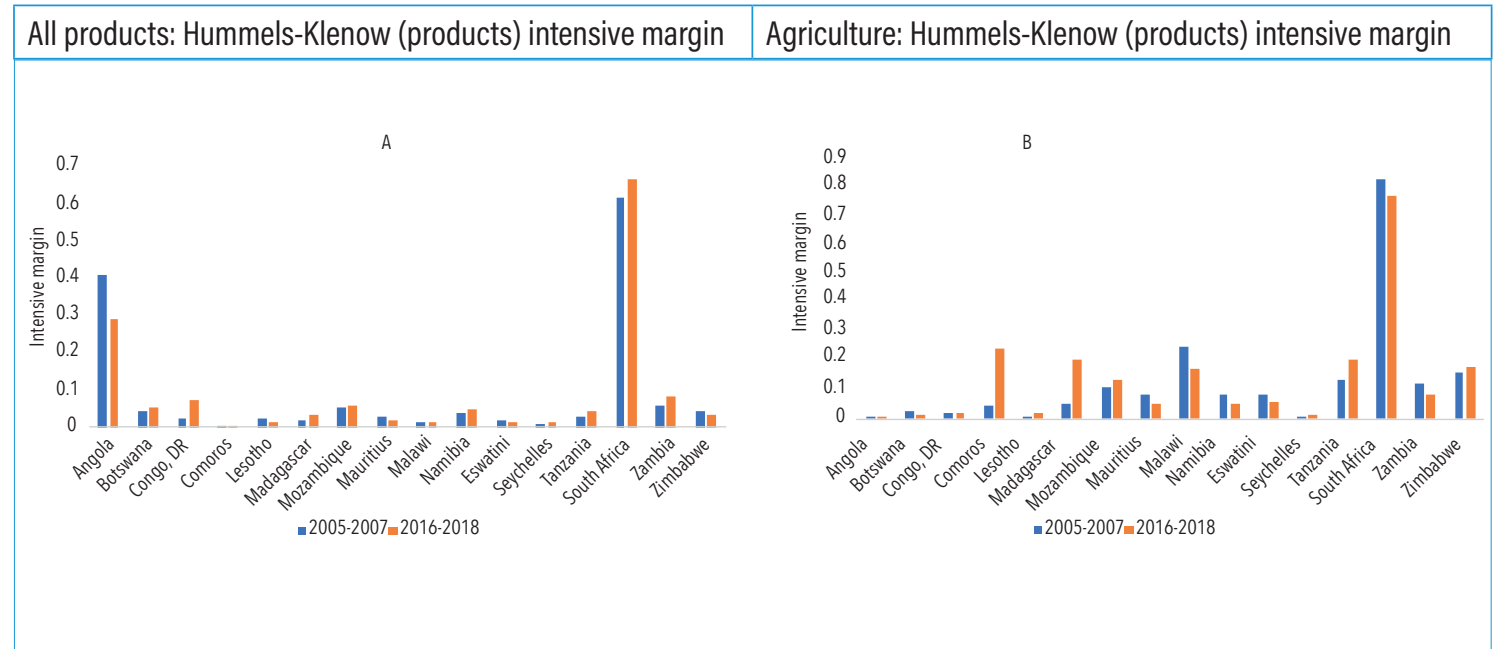

Source: 2020AATM database and author calculations.

Figure 6.7 Hummels and Klenow extensive margins

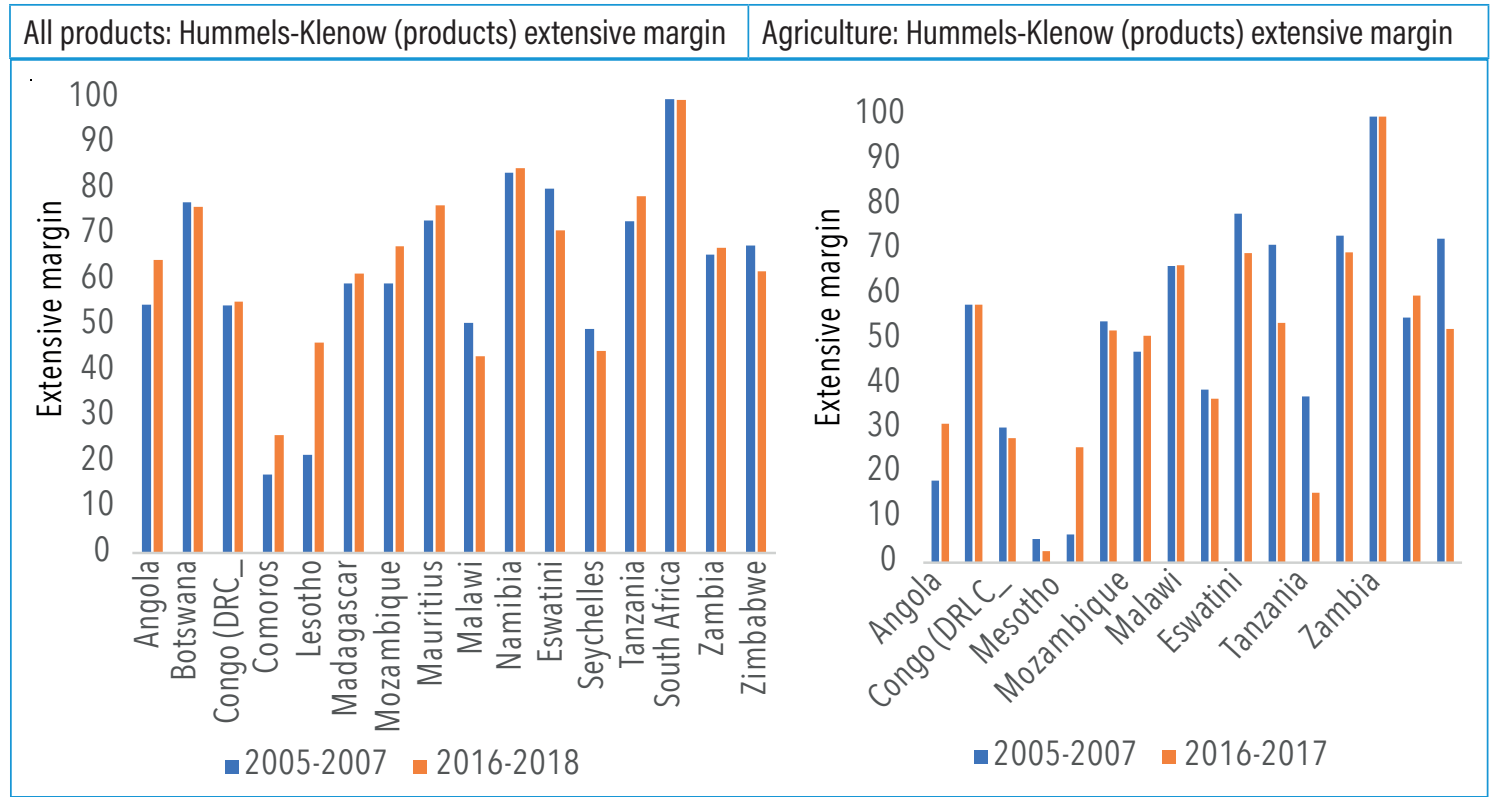

Source: 2020 AATM database and author calculations.

\section{Regional value chain development in agro-processing}

There is a strong correlation between the extent of regional integration and global value chains trade. Most trade agreements in Africa are still "shallow," which hampers development of regional value chains. They are shallow because they impose a high tariff on manufactured and agricultural goods, as well as export taxes and many nontariff barriers. Bilateral trade protection among African countries affects backward and forward participation in regional agriculture and food value chains. The immediate challenge facing SADC negotiations on regional value chains integration is to address the distortions created by traditional barriers to trade within Africa (World Bank 2020b). With the progress of AfCFTA, there is widespread optimism throughout the continent that increased trade integration will strengthen the emerging regional value chains and enable firms throughout Africa to participate in global value chains. 
Participation in regional value chains is critical to SADC countries' export growth. Value chains are increasingly important as a source of investment and exports, but also as a channel to access knowledge and technology to support productivity growth. SADC countries should identify their comparative advantages to fully participate backward and forward in global value chains (World Bank 2020b). SADC's industrialization policy framework emphasizes the need for processing and value addition.

Southern Africa's participation in global value chain trade is limited by various constraints. The World Bank's 2020 World Development Report finds that, in 2014, agricultural exports accounted for 2 percent of world exports in contrast to 60 percent for manufacturing exports and 20 percent for services exports. The report identifies sluggish economic growth, slow pace, and reversal in trade reforms, as well as reduced incentives to outsource and increased production at home by China and the United States as major barriers to regional value chain development. SADC countries continue to be net importers of food despite being endowed with agriculture goods. UNECA (2018) points out that Zambia and Zimbabwe have agriculture value chain potential, but low technological investment, and policy misalignments have limited their capacity to add value. The World Development Report identified the SADC countries DRC, Namibia, Tanzania, and Zimbabwe as countries that could derive higher welfare gains from reductions in tariffs and NTMs.

South Africa dominates again in value chains, accounting for most of the intermediate goods exported and imported within SADC. Black et al. (2019) find that while SADC has very limited forward linkages into regional value chains, South Africa is by far the main source of value-added exports. Table 6.3 is a country-level matrix showing the total amount (in millions of US dollars) of intermediate products exported and imported by each SADC country over the period 20032017. Angola appears to export a large share of intermediate goods to the DRC ( $\$ 5.6$ million) and Namibia (\$2.9 million), but it also imports a lot of these products from South Africa ( $\$ 744.6$ million) and Namibia (\$160.7 million). South Africa is the only country that exports and imports significant amounts of intermediate goods to all the SADC member countries, followed by Zimbabwe, Tanzania, and Zambia. Trade in intermediate goods in SADC appears to be agglomerated and inversely related to distance. For example, South Africa exports a lot to its neighbors Zimbabwe, Botswana, Namibia, and Lesotho and imports a lot from Eswatini, Namibia, and Zimbabwe. DRC also imports a lot from Tanzania and Zambia. Trend analysis shows that South Africa has managed to increase its trade of intermediate products in SADC. 
Table 6.3 Matrix of total exports and imports of intermediate goods traded in the SADC region (2003-2017), US\$ millions

\begin{tabular}{|c|c|c|c|c|c|c|c|c|c|c|c|c|c|c|c|c|c|}
\hline \multicolumn{2}{|c|}{ 2003-2017 } & \multicolumn{16}{|c|}{ EXPORTING COUNTRIES } \\
\hline \multirow{17}{*}{ 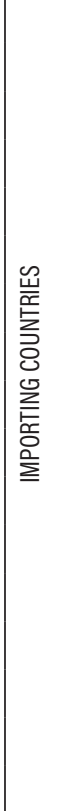 } & & AGO & BWA & COM & $\operatorname{coD}$ & SWZ & LSO & MDG & MUS & MWI & MOZ & NAM & SYC & ZAF & TZA & ZMB & ZWE \\
\hline & Angola (AGO) & - & 0.4 & 0 & 0.1 & 0.01 & 0.8 & 0 & 0.7 & 0.3 & 3.2 & 160.7 & 0 & 744.6 & 19.1 & 18 & 4.3 \\
\hline & Botswana (BWA) & 1.03 & - & 0 & 0.05 & 8.8 & 3.5 & 0 & 23.7 & 14.4 & 0.3 & 8 & 0 & 2330.2 & 0.2 & 79.1 & 132.9 \\
\hline & Comoros (COM) & 0 & 0 & - & 0 & 0 & 0 & 3.5 & 16.4 & 0 & 1.4 & 0.01 & 0 & 13.6 & 10.8 & 0 & 0.04 \\
\hline & DRC (COD) & 5.6 & 2.5 & 0 & - & 0.06 & 0 & 0 & 0 & 13.8 & 0 & 24.1 & 0 & 247.2 & 604.9 & 1060.5 & 10.3 \\
\hline & Eswatini (SWZ) & 0 & 2 & 0 & 0.2 & - & 0.7 & 1.5 & 0.7 & 33.5 & 32.1 & 0.1 & 0.5 & 1405.2 & 20.4 & 46.2 & 1.8 \\
\hline & Lesotho (LSO) & 0 & 6.1 & 0 & 0 & 0.8 & - & 0.04 & 6.3 & 7.3 & 1.6 & 0.01 & 0 & 1642.7 & 0 & 42.5 & 31.6 \\
\hline & Madagascar (MDG) & 0 & 0 & 0 & 0.4 & 47.1 & 0.2 & - & 135.8 & 11.5 & 19.5 & 0 & 0.02 & 250.4 & 5.6 & 4.6 & 2.1 \\
\hline & Mauritius (MUS) & 0.03 & 0.1 & 6.4 & 0 & 2.2 & 0.3 & 187 & - & 23.4 & 130.9 & 0.8 & 0.8 & 319.6 & 45.4 & 385.4 & 51.7 \\
\hline & Malawi (MWI) & 0 & 0.7 & 0.2 & 0.2 & 14.6 & 0 & 0 & 5.2 & - & 430.5 & 0.1 & & 291.3 & 79.9 & 748.2 & 54.4 \\
\hline & Mozambique (MOZ) & 0.01 & 0.3 & 0 & 0 & 108.7 & 0.1 & 1.4 & 103. & 145.5 & - & 0.1 & 10 & 1126.4 & 15.2 & 58.9 & 960 \\
\hline & Namibia (NAM) & 2.9 & 10.9 & 0 & 0.01 & 2.4 & 0 & 0 & 2.7 & 0.3 & 2.5 & - & 0 & 1886.5 & 0.5 & 143.6 & 30.2 \\
\hline & Seychelles (SYC) & 0 & 0 & 0 & 0 & 0.01 & 0 & 2.5 & 38.4 & 1.6 & 0 & 0 & - & 20.5 & 14.9 & 0 & 0.7 \\
\hline & South Africa (ZAF) & 1.3 & 185.3 & 0.04 & 8.5 & 1992.6 & 458.6 & 10.6 & 81.4 & 361.0 & 448.7 & 2246.4 & 0.2 & - & 117.6 & 794.4 & 1198.6 \\
\hline & Tanzania (TZA) & 0 & 0.7 & 0 & 0.6 & 28.6 & 0 & 0 & 23.3 & 116.4 & 35.6 & 0.01 & 0 & 211.2 & - & 260.5 & 9.8 \\
\hline & Zambia (ZMB) & 0 & 5.5 & 0 & 4.2 & 5.5 & 0.02 & 0 & 53.3 & 135.2 & 34 & 18.1 & 6.3 & 1068.1 & 55.5 & - & 143.8 \\
\hline & Zimbabwe (ZWE) & 0 & 69 & 0 & 1.4 & 4.2 & 0.02 & 0.1 & 119.4 & 469.2 & 299.1 & 5.7 & 14.4 & 3012.1 & 14.9 & 1770 & - \\
\hline
\end{tabular}

Source: 2020 AATM database.

\section{Potential explanation of SADC intraregional trade flows}

For the period 2010-2018, the level of intraregional trade in Southern Africa has not changed much, and the graduation of SADC and COMESA ${ }^{7}$ into free trade areas in 2008 and 2000, respectively, has done little to spur intraregional trade growth. SADC intraregional trade as a percentage of the region's world trade was 19 percent in 2008 and rose only to 19.4 percent in 2019 (ITC 2020). SACU intraregional trade has never exceeded 16 percent since 2000, but intraregional exports jumped from a low of 4.5 percent in 2009 and have remained above 13 percent since 2010. This is the case even though SACU is the most integrated regional bloc in terms of trade in Africa south of the Sahara (SSA).

At the country-level, intraregional trade is heavily skewed toward South Africa and the country has consistently enjoyed a positive trade balance with the regional member states (Figures 6.2, 6.3, 6.8, and 6.9). South Africa is by far the biggest economy in the SADC region, contributing more than 60 percent of regional GDP; its huge appetite for intermediate goods may also be partly explained by the size of its manufacturing sector, which accounts for around 68 percent of the regional manufacturing output (World Bank 2020c). The country also contributes on average 27 percent of the region's agricultural output and its supermarkets chains, Pick n Pay and Shoprite, are found in 10 of the 16 SADC countries, exporting a large variety of retail products (World Bank 2020c; Das Nair 2018). Countries including the Seychelles, Tanzania, Angola, Madagascar, and Malawi trade and export the least within the region. Economic size, industrial development, tariffs, and nontariff barriers to trade could be some of the factors influencing the magnitude, shape, and direction of trade flows in SADC.

7 Nine SADC countries are members of COMESA. 
Figure 6.8 Country intra-SADC total export and import shares (percent), 2010-2018

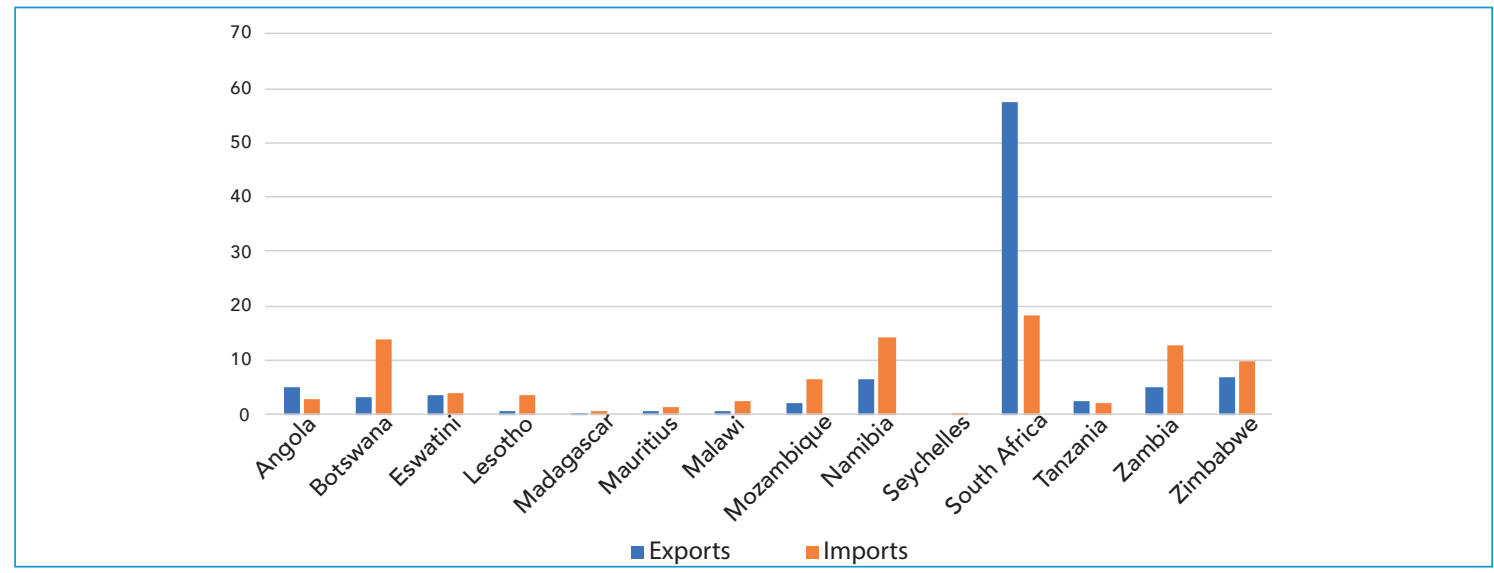

Source: ITC TradeMap 2020.

Note: No data available for DRC and Comoros.

Figure 6.9 Exports and imports of intermediate goods within SADC (US\$ millions), 2003-2018

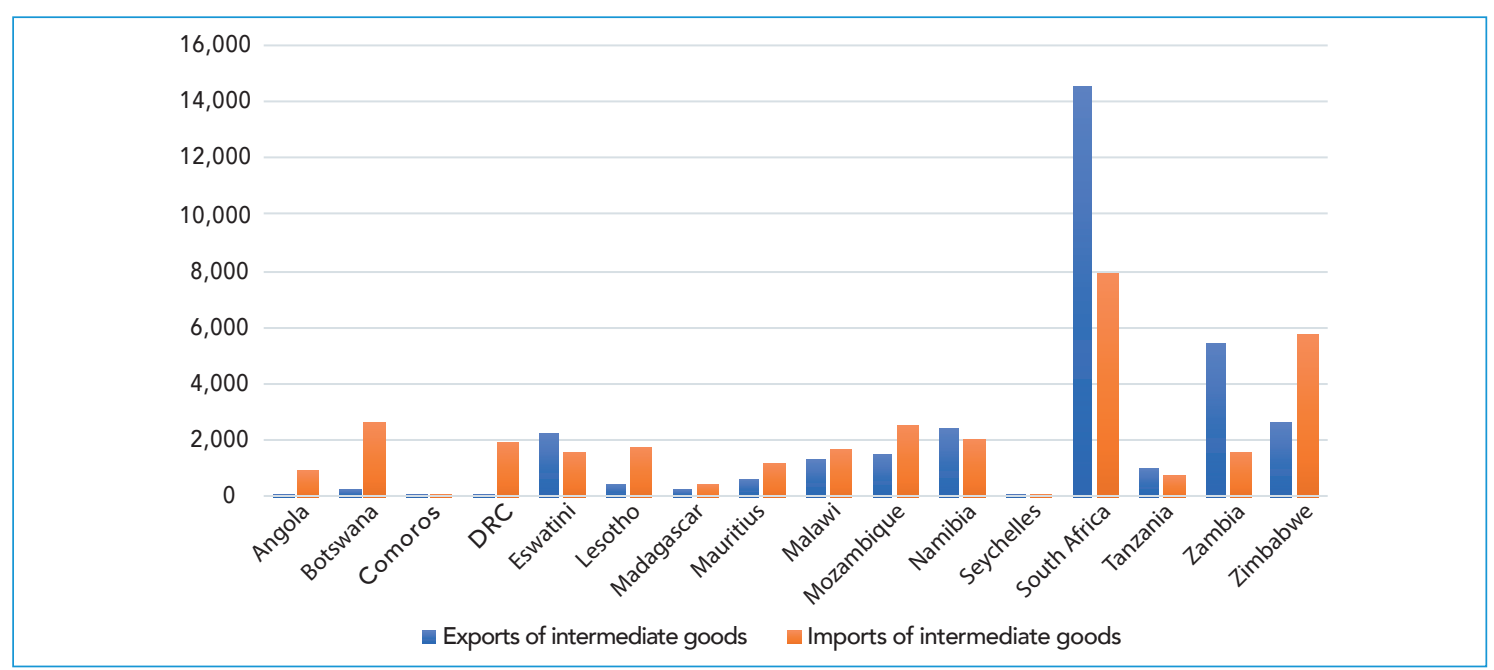

Source: 2020 AATM database.

South Africa's large size may partly explain why trade is skewed toward the country, but size does not explain why the region's next three biggest economies - Angola, ${ }^{8}$ Tanzania, and Mozambique - are faring badly and worse than smaller regional countries like Namibia, Zambia, and Zimbabwe. However, the growing manufacturing sector in Zambia (third largest in the region after Angola) is probably driving its exports of intermediate goods, while Zimbabwe's economic crisis increases its dependence on imported products.

Although Africa is sometimes considered to be the least open continent (see above), SADC and SACU have ad valorem equivalent tariff levels lower than the African average and are the least protected compared to other selected regional blocs (Figure 6.10). At the country level, data show that DRC, Seychelles, Tanzania, Zambia, and Zimbabwe have higher than average agriculture ad valorem tariff equivalents, which may partly explain the relatively low intra-SADC agricultural import shares in these countries (Figure 6.10). Seychelles has the highest average tariff level on agriculture, which could explain why the country has the lowest agriculture import share (Figure $6.9)$.

8 Civil war in Angola ended after 27 years in 2002 and the country has been on a rebuilding journey. This probably partly explains why the country refused to join the SADC-FTA. 
Figure 6.10 Average ad valorem equivalent of import duties applied, 2011

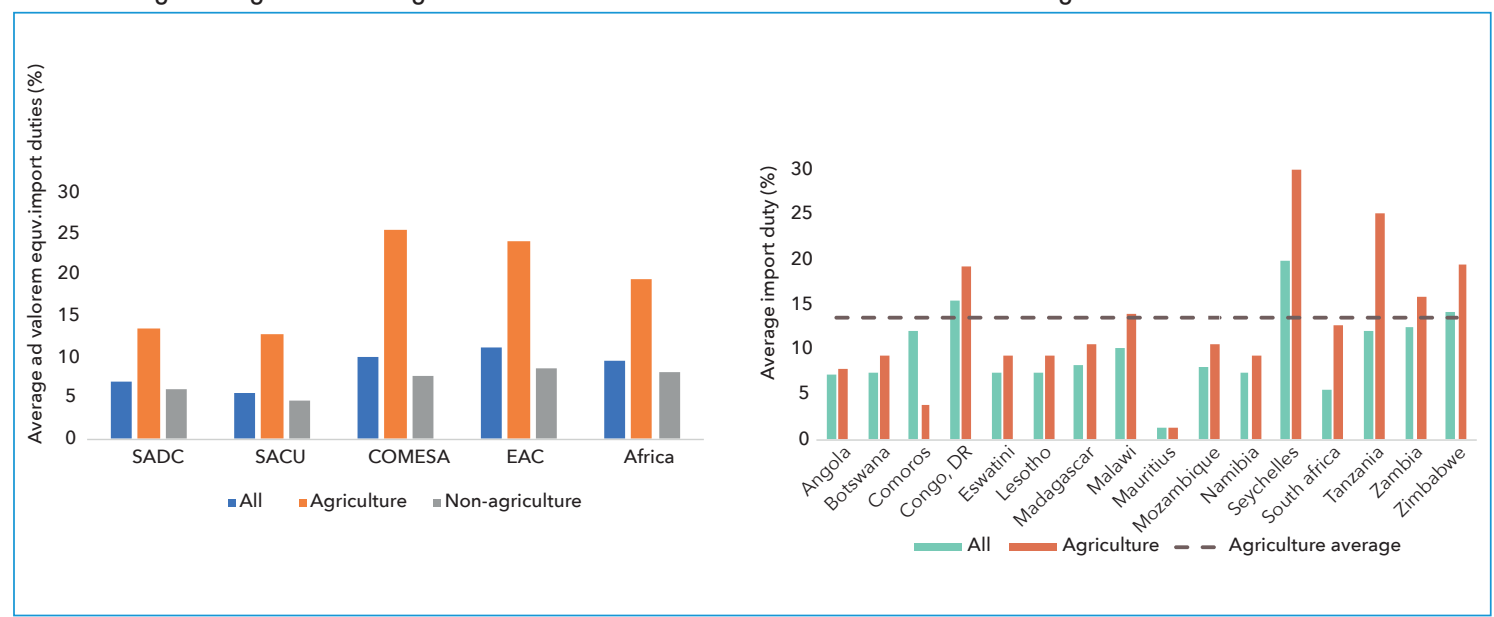

Source: Bouët et al. (2017) using MacMap HS6 (CEPII 2011).

Athough Mauritius appears to have the lowest general tariff rates, its share of intraregional imports of finished and intermediate goods is very low. Countries including Zimbabwe and DRC charge relatively higher tariff rates but import a large share of these products from other SADC countries. Madagascar and Malawi also have a smaller share of intra-SADC imports than Zambia and Zimbabwe, although Zambia and Zimbabwe impose relatively higher average tariffs. Ackah and Morrissey (2013) found little aggregate evidence that the trade policy reforms in SSA have produced a significant export response, arguing that trade has not increased consistently nor in tandem with the magnitude of liberalization. Babatunde (2009) found similar results using average tariff rates of 20 SSA countries.

The environment in which production decisions are made may also constrain the supply response. Infrastructure and trade facilitation are important components of trade costs and may affect trade growth (Shepherd 2016). The 2019 integration indices calculated by the African Union together with AfDB and UNECA show that the SADC infrastructure integration index dropped from 0.5 in 2016 to 0.2 in 2019. This decline may explain not only the fall in productive integration from 0.35 to 0.24 but also the decrease in trade integration from 0.5 to 0.34 . The decreasing quality of hard infrastructure such as highways, railroads, water, electricity as well as soft infrastructure like customs and port efficiency could be another source of intraregional trade friction.

Transportation infrastructure development across the region is the most visible face of integration, especially given that seven countries in the SADC region are landlocked and even countries with seaports also have large interiors. Improving the quality of roads, rail, seaports, and airports will reduce trading costs and possibly increase the volume of trade. Shepherd $(2016,20)$ argues: "There is a strong positive association between infrastructure and trade facilitation improvements in neighbouring countries, and therefore it is not just what a country does that matters for its connectivity, but also what its neighbours do."

Because the SADC region exports several bulky minerals and agricultural products (cotton, tobacco, tea, coffee, beef, sugar, horticultural products, etc.) and is a large importer of oil, machines, vehicles, and consumer goods, the region needs functioning, well-maintained, and integrated transport systems (Peters-Berries 2010). However, the quality of infrastructure varies markedly within the region. The Global Competitiveness Reports, which rank countries in terms of the quality of their infrastructure, show that Seychelles has maintained its number one ranking in Africa since 2016, while the performance of other SADC countries is erratic. Angola is the only country whose 
ranking has improved since 2017, and the number of SADC countries ranked in the top ten has fallen from three in 2016 to two in 2017-2019 (World Economic Forum 2016-2019).

When we look specifically at the quality of roads, electricity supply, and water, the infrastructure scores of most countries, including Seychelles, are very low (Table 6.4). For the period 2014-2019, the quality of roads in Seychelles is lower than that of Mauritius, Namibia, and South Africa, and the quality of electricity supply is lower than that of Namibia and Mauritius. The low quality of infrastructure may partly explain the relatively high levels of intraregional trade in South Africa (38 percent) and Namibia (10 percent) (Figure 6.8). Namibia and Mauritius are the only SADC countries whose infrastructure scores are closer to those of the world's top performers in the infrastructure category (Table 6.4). The relatively high scores of countries like South Africa, Botswana, and Namibia partly explain why intraregional trade appears concentrated in these countries (Figure 6.8 and Table 6.4).

Table 6.4 Comparison of infrastructure quality between SADC and top performing countries

\begin{tabular}{|c|c|c|c|c|c|c|c|c|c|}
\hline & \multicolumn{4}{|c|}{ Quality of road infrastructure } & \multicolumn{4}{|c|}{ Quality of electricity supply } & \multirow{2}{*}{$\begin{array}{l}\text { Reliability of } \\
\text { water supply } \\
2019 \\
\end{array}$} \\
\hline & 2012 & 2014 & 2016 & 2019 & 2012 & 2014 & 2016 & 2017 & \\
\hline Angola & 2.5 & 2.3 & --- & 2.2 & 1.4 & 1.7 & --- & -- & 2.1 \\
\hline Botswana & 4.4 & 4.0 & 4.0 & 3.8 & 3.5 & 2.4 & 2.7 & 3.7 & 3.9 \\
\hline Eswatini & 5.0 & 4.9 & 4.4 & 4.0 & 3.8 & 4.1 & 4.0 & 3.7 & 4.5 \\
\hline Lesotho & 2.7 & 3.3 & 3.6 & 2.7 & 3.9 & 3.7 & 3.7 & 2.9 & 3.2 \\
\hline Madagascar & 2.7 & 2.6 & 2.2 & 2.0 & 2.3 & 2.3 & 1.9 & 1.9 & 2.3 \\
\hline Malawi & 3.7 & 3.3 & 3.2 & 2.8 & 1.9 & 2.9 & 2.7 & 1.9 & 3.0 \\
\hline Mauritius & 4.1 & 4.8 & 4.8 & 4.7 & 5.1 & 5.5 & 5.4 & 5.5 & 4.3 \\
\hline Mozambique & 2.3 & 2.1 & 2.3 & 2.4 & 3.3 & 3.1 & 2.9 & 3.0 & 2.6 \\
\hline Namibia & 5.4 & 5.2 & 5.2 & 5.3 & 5.6 & 5.4 & 5.4 & 5.5 & 5.3 \\
\hline Seychelles & --- & 4.2 & 4.2 & 4.0 & --- & 4.8 & 4.8 & 5.0 & 4.9 \\
\hline South Africa & 4.8 & 4.9 & 5.0 & 4.5 & 3.7 & 3.6 & 2.9 & 3.9 & 4.4 \\
\hline Tanzania & 3.2 & 3.0 & 3.3 & 4.1 & 2.2 & 2.5 & 2.6 & 3.1 & 3.6 \\
\hline Zambia & 2.9 & 3.6 & 3.7 & 3.4 & 3.5 & 3.3 & 3.3 & 2.5 & 3.3 \\
\hline Zimbabwe & 3.3 & 3.3 & 3.3 & 2.8 & 1.7 & 2.1 & 1.9 & 3.1 & 2.3 \\
\hline \multicolumn{10}{|c|}{ Top five best performing countries in the world (2012) } \\
\hline Hong Kong & 6.3 & 6.0 & 6.2 & 6.1 & 6.8 & 6.8 & 6.8 & 6.8 & 6.8 \\
\hline Singapore & 6.5 & 6.1 & 6.3 & 6.5 & 6.7 & 6.7 & 6.8 & 6.9 & 6.8 \\
\hline Germany & 6.1 & 5.9 & 5.6 & 5.3 & 6.4 & 6.1 & 6.4 & 6.2 & 6.1 \\
\hline France & 6.5 & 6.2 & 6.0 & 5.4 & 6.7 & 6.5 & 6.7 & 6.8 & 6.5 \\
\hline Switzerland & 6.4 & 6.0 & 6.0 & 6.3 & 6.8 & 6.8 & 6.9 & 6.9 & 6.9 \\
\hline
\end{tabular}

Source: World Economic Forum, Global Competitiveness Index (2012-2019).

Note: A high score means good quality. For example, in the case of water, 1 means water supply is extremely unreliable while 7 means extremely reliable. SADC countries not covered have no data. Although the rankings change every year, the top five best performing countries have always remained in the top ten.

The relatively poor quality of infrastructure in SADC is confirmed in part by the World Bank Enterprise Surveys (2020a), which show that more than a quarter of firms surveyed identified transport as a major constraint to doing business in Mauritius, Lesotho, Angola, and Namibia (Figure 6.11). Electricity challenges, proxied by percentage of firms that own and operate generators, appear to be severe in Angola, DRC, Eswatini, Tanzania, and Zimbabwe, while firms that identified electricity as a major challenge are primarily in DRC, Mauritius, and Tanzania. ${ }^{9}$ However, in Botswana,

9 Unfortunately some of these survey statistics are not up to date and may not reflect current status quo. 
Namibia, South Africa, Zambia, and Zimbabwe, countries with relatively high levels of intraregional trade, very few firms complained about infrastructure quality (Figures 6.8 and 6.11).

Figure 6.11 Firms identifying infrastructure as a major constraint in the SADC region

Source: World Bank Enterprise Surveys (2020a).

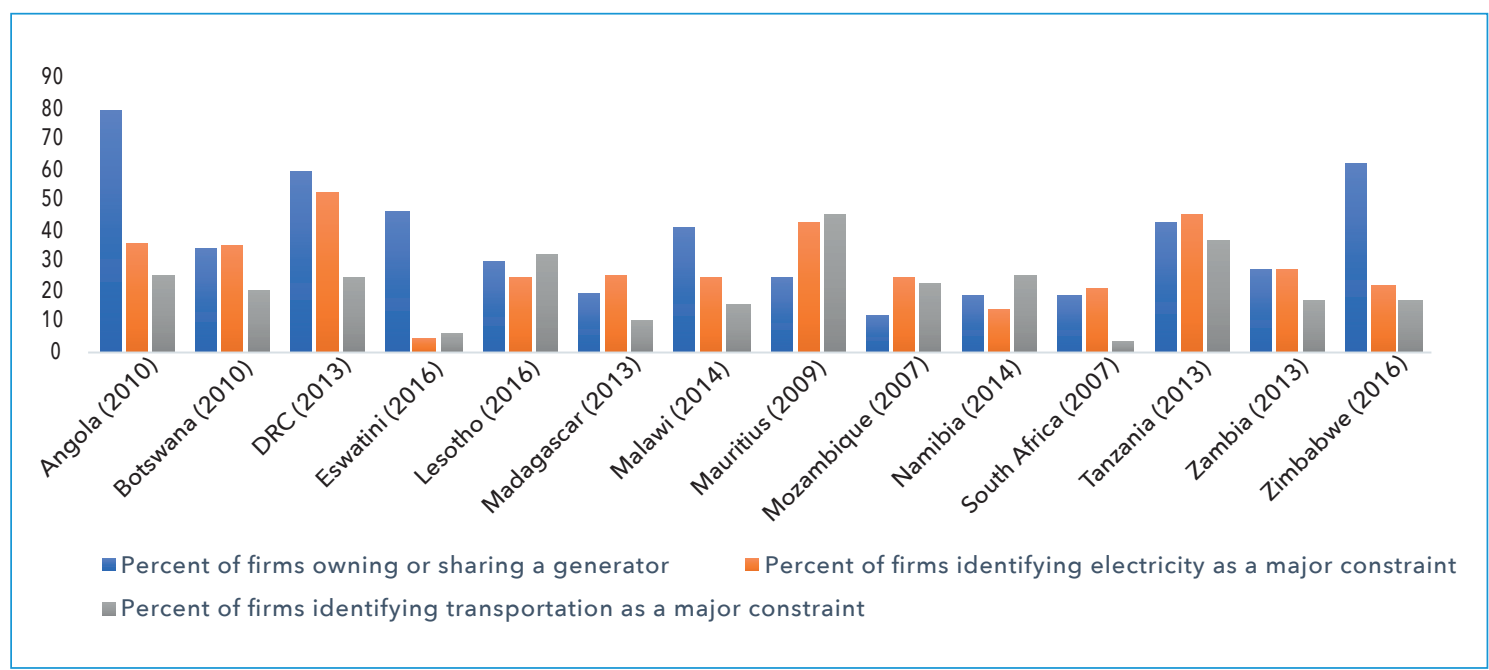

Customs infrastructure also plays a crucial role in facilitating trade and regional integration, and we proxy it using border compliance hours. These costs of trading across borders vary widely among countries (Table 6.5). Of the 16 countries, only 6 are ranked in the top 10 (that is, have the lowest border compliance hours) in the whole of SSA; Angola, DRC, and Tanzania are the worst performers. Although time to export appears to be declining or constant, it generally takes less time to both export and import in the small countries of the region, probably because of the relatively small flow of goods in these countries. Namibia is the only country where there is a big divergence between border compliance hours for exports and border compliance hours for imports - it takes about 120 hours to export but twenty times less to import. This disparity partly explains why Namibian regional imports far outweigh exports (Table 6.5). In Angola, DRC, Namibia, Tanzania, Zambia, and Zimbabwe, it generally takes more than 100 hours to either export or import, which may explain why the share of traded agricultural, intermediate, and finished goods is low and, in some instances, declining. Long border crossing hours translate into high trade costs and a serious hindrance to trade. These SADC member countries need to learn from the experience of other countries in the region, like Botswana, Eswatini, Lesotho, and Mauritius, and improve conditions for trading across borders. 
Table 6.5 Customs infrastructure: Trading across borders

\begin{tabular}{l|l|llll|llll}
\hline & $\begin{array}{l}\text { Ranking } \\
\text { (out of 48) }\end{array}$ & \multicolumn{3}{l|}{$\begin{array}{l}\text { Time to export } \\
\text { (border }\end{array}$} & compliance hours) & \multicolumn{4}{l}{$\begin{array}{l}\text { Time to import } \\
\text { (border compliance hours) }\end{array}$} \\
\cline { 2 - 10 } & $\mathbf{2 0 1 9}$ & $\mathbf{2 0 1 6}$ & $\mathbf{2 0 1 7}$ & $\mathbf{2 0 1 8}$ & $\mathbf{2 0 1 9}$ & $\mathbf{2 0 1 6}$ & $\mathbf{2 0 1 7}$ & $\mathbf{2 0 1 8}$ & $\mathbf{2 0 1 9}$ \\
\hline Angola & 38 & 312 & 312 & 192 & 164 & 276 & 276 & 96 & 72 \\
Botswana & 3 & 8 & 8 & 5 & 5 & 4 & 4 & 4 & 4 \\
Comoros & 13 & 51 & 51 & 51 & 51 & 70 & 70 & 70 & 70 \\
DRC & 47 & 515 & 515 & 515 & 296 & 588 & 588 & 588 & 336 \\
Eswatini & 1 & 3 & 3 & 2 & 2 & 5 & 5 & 3 & 3 \\
Lesotho & 2 & 4 & 4 & 4 & 4 & 5 & 5 & 5 & 5 \\
Madagascar & 21 & 70 & 70 & 70 & 70 & 105 & 99 & 99 & 99 \\
Malawi & 18 & 85 & 85 & 78 & 78 & 64 & 55 & 55 & 55 \\
Mauritius & 4 & 48 & 48 & 38 & 24 & 51 & 51 & 41 & 41 \\
Mozambique & 6 & 78 & 78 & 66 & 66 & 14 & 14 & 14 & 9 \\
Namibia & 20 & 120 & 120 & 120 & 120 & 6 & 6 & 6 & 6 \\
Seychelles & 8 & 84 & 82 & 82 & 82 & 99 & 97 & 97 & 97 \\
South Africa & 24 & 92 & 92 & 92 & 92 & 87 & 87 & 87 & 87 \\
Tanzania & 42 & 96 & 96 & 96 & 96 & 402 & 402 & 402 & 402 \\
Zambia & 26 & 148 & 148 & 120 & 120 & 163 & 163 & 120 & 120 \\
Zimbabwe & 29 & 88 & 88 & 88 & 88 & 60 & 228 & 228 & 228 \\
\hline
\end{tabular}

Source: World Bank Doing Business (2016-2019).

One approach that is being used to minimize the amount of time lost at the border posts are OneStop Border Posts (OSBP). SADC has included the creation of these joint customs control facilities in its core mandate and in 2011 issued Draft Guidelines on Coordinated Border Management. Although plans are underway to convert the region's busiest border - between Zimbabwe and South Africa (Beitbridge) - into a one-stop facility, there is still no OSBP in the region (Tralac 2018). The United Nations Conference on Trade and Development (UNCTAD) is also helping to streamline customs clearance with development of an automated system for customs data (ASYCUDA) to reform customs-clearing procedures, and the World Customs Union has developed standard nomenclature that customs officials can use to code traded goods. However, some SADC countries, including Angola, South Africa, Mauritius, Namibia, Madagascar, and Mozambique, have not yet adopted either the ASYCUDA system or the harmonized commodity description and coding system, which may be one of the factors derailing the implementation of OSBP and impeding border efficiency.

\section{The future of the AfCFTA and Southern Africa}

Given that SADC became a fully-fledged free trade zone in 2012 and has the lowest internal tariffs among the regional blocs, elimination of unnecessary nontariff barriers should be the next step in fostering integration. The signing and ratification of the AfCFTA on May 30, 2019, makes this more important than ever before. Simulation results on the AfCFTA show that benefits from liberalization are very high when nontariff barriers are minimal. Kalaba (2014) documents that, in 2010, most SADC countries applied more than 300 NTMs on imports of agricultural goods, with South Africa having the most at 600 . Eighty percent of these NTMs were in the form of sanitary and phytosanitary standards, followed by licensing and quantitative restrictions as well as technical 
barriers to trade. Most of the NTMs were on products such as beverages, spirits, vinegar, fruits, meat, and dairy products.

Although all the SADC countries have signed the AfCFTA, only 5 of the 16 countries have ratified the agreement. The remaining 11 SADC countries should speed up their ratification of the agreement, and countries should develop strategies for minimizing NTMs and exploiting the new trade opportunities. In the future, SADC's intraregional trade growth should no longer be restricted by its 203 million people but expand to the continent's more than 1.2 billion people. Although intraSADC tariff levels are generally lower than those in other RECs, the gradual reduction of tariffs through the AfCFTA will help lessen SADC's external export tariffs. To maximize welfare benefits from the AfCFTA, SADC member countries need to liberalize in a way that promotes trade creation and should therefore consider what other regional blocs are doing.

\section{Conclusions and the way forward}

Regional integration in Southern Africa dates back as far as 1910, when the SACU was formed. The SADC was formed in 1980, achieved free trade area status in 2008, and became a fully-fledged free trade area in 2012. All SADC countries are part of the SADC-FTA, except Angola, DRC, and the Comoros, which joined the bloc only in 2017. Of the five stages of regional integration, SADC has achieved only one, and most of the region's integration milestone deadlines have been missed. Harmonization of different common external tariff lines levied by member countries should be expedited so that SADC can graduate into a customs union. The problem of overlapping membership, which is widespread in the continent, is common in Southern Africa, with all of the Southern Africa countries except Angola and Mozambique belonging to more than one REC. Implementation of the AfCFTA may help to harmonize these regional integration arrangements and boost the smooth flow of traded goods.

Since 2010, intraregional trade in Southern Africa has not changed much, and the graduation of SADC and COMESA into free trade areas in 2008 and 2000 respectively has done little to spur trade growth. The trade integration indices calculated by the African Union, AfDB, and UNECA in 2016 also confirm that intraregional trade is low in SADC, just over 20 percent of SADC world exports. The picture is likewise disappointing at the country level. Excluding South Africa, intraregional trade accounts for less than 10 percent of trade in all the SADC countries, with the Seychelles being the smallest importer and exporter. Thus, SADC like Africa as a whole still trades very little with itself as compared to the rest of the world. This suggests that the formation of the FTA has not translated into huge trade benefits. The predominance of South Africa in the region crowds out and dwarfs the benefits that other member countries enjoy. It is of concern for integration that South Africa accounts for over 60 percent of intra-SADC total exports and agricultural exports, indicating that trade benefits are skewed. Although this predominance is justified by the country's economic size, equitable distribution of integration benefits is important for garnering the political will and support needed to improve intraregional trade conditions.

The extent of regional integration is related to participation in global value chains. Increased trade integration strengthens emerging regional value chains and enables firms throughout the region to participate in global value chains as well. SADC countries need to identify their comparative advantages, especially in agriculture, in order to fully participate in both backward and forward value chains in line with the region's industrialization strategy. Limited investment in technology and policy misalignments discourage value addition. A recent review of industrialization policies 
in the region (UNECA 2018) identified several production areas, in both mining and agriculture (cotton, fruits, marine products), where there are immense investment opportunities available to the private sector for processing and value addition within a regional value chain.

Although SADC and SACU show higher levels of introversion compared to other African RECs, only 30 percent of total agricultural exports are traded within the region and intra-SADC agricultural trade is around 47 percent of total trade. Supply-side bottlenecks including input shortages and use of obsolete technology together with inefficient infrastructure are some of the constraints that need addressing. Given that 25 percent of the SADC land mass is arable and only 6 percent is currently being farmed (SADC 2012), relatively good climatic conditions should help the region exploit this untapped agricultural potential to produce and export large quantities of agricultural goods, ideal for promoting agricultural value chains. However, climate change poses some risks. Some countries are now experiencing lower than normal rainfall, and the 2019 cyclone Idai caused catastrophic damage that created a humanitarian crisis in Malawi, Mozambique, and Zimbabwe. Climate change threatens lives and livelihoods, and measures must be developed to mitigate the impact of these changes. Agricultural trade growth is also affected by the higher average ad valorem equivalent import duties imposed by countries including DRC, Seychelles, Malawi, Zambia, and Zimbabwe. Overprotection of the agriculture sector is uncompetitive and works against its productivity, negatively affecting food security, livelihoods, and welfare.

Understanding the major frictions impeding intraregional trade growth is very important in designing effective trade strategies. Poor quality of transport, electricity, and customs infrastructure constitute NTMs. This infrastructure needs to be improved to deepen integration in the region. Implementation of both hard and soft infrastructure projects identified in the 2012 SADC Regional Infrastructure Development Master Plan as well as rapid implementation of the SADC Industrialisation Strategy and Road Map (2015-2063) will not only increase and smooth the flow of goods but also help to increase local competitiveness and expand regional value chains. Improving infrastructure quality is also key to achieving higher intraregional trade levels. Although the Protocol on Transport, Communications and Meteorology was signed by SADC member states in 1996, there is still much that needs to be done to improve infrastructure in the region. Although several public-private partnership (PPP) projects have been implemented in some countries, there have been no PPP projects in Eswatini, Lesotho, or Malawi since 2010, and the governments continue to fund all infrastructure-related projects (WDI 2020). Mozambique, South Africa, and Zambia are the only countries that have partnered with the private sector and invested billions of US dollars in infrastructure development. Thus, effective implementation of the 2011 SADC Guidelines on Coordinated Border Management and the SADC Regional Infrastructure Development Master Plan is important to improve the quality of the region's infrastructure.

The SADC Industrialisation Strategy launched in 2015 provides useful guidance on what structural reforms and enhanced competitiveness measures countries need to implement to maximize benefits from free trade and the AfCFTA. This strategy is anchored on industrialization as a driver of economic and technological transformation and makes industrialization the fulcrum of regional integration. Agro-processing, mineral beneficiation, and downstream processing are some of the potential growth paths identified. The strategy recognizes that improving agricultural productivity, as proposed in SADC's Regional Agricultural Policy, is important for the development of agroindustries and agricultural value chains. Rural industrialization support to locate agro-processing industries in rural areas, facilitate rural industrial clusters, and make agriculture and agroprocessing attractive professions is the modus operandi proposed by the region.

A look at the SADC website shows a number of promising strategies for ramping up trade and integration in the region, ranging from the SADC Industrialisation Strategy and Roadmap (2015), Regional Infrastructure Development Master Plans (2012) that cover water, information and 
communications technologies (ICT), transport, and meteorology, SADC Resources Mobilization Strategy (2012), Private Sector Involvement Strategy in Customs Matters (2013), Regional Indicative Strategic Development Plan (2001), Customs ICT Strategy of 2013, and Regional Agricultural Policy (2014). What is needed is strong political will and leadership from regional member states to effectively implement all the measures agreed upon in these strategies.

\section{References}

Ackah, C., and O. Morrissey. 2013. Trade Policy and Performance in Sub Saharan Africa since the 1980s. Credit Research Paper No 05/13. University of Nottingham, UK.

AfDB (African Development Bank). 2019. Southern Africa Economic Outlook. Abidjan.

Arvis, J. F., D. Saslavsky, L. Ojala, B. Shepherd, C. Busch, A. Raj, and T. Naula. 2016. Connecting to Compete 2016: Trade Logistics in the Global Economy: The Logistics Performance Index and Its Indicators. World Bank.

AUC (African Union Commission). 2016. Africa Regional Integration Report. United Nations Economic Commission for Africa and African Development Bank.

AUC. 2019. Africa Regional Integration Report. United Nations Economic Commission for Africa and African Development Bank.

Babatunde, A. M. 2009. "Can Trade Liberalization Stimulate Export Performance in Sub Saharan Africa?" Journal of International and Global Studies 2 (1): 68-92.

Behar, A., and L. Edward. 2011. How Integrated is SADC? Trends in Intra-Regional and Extra-Regional Trade Flows and Policy. Washington, DC: World Bank.

Black, A. H., L. Edwards, F. Ismail, B. Makundi, and M. L. Morris. 2019. "Spreading the Gains? Prospects and Policies for the Development of Regional Value Chains in Southern Africa." WIDER Working Paper 2019/48, UNU-WIDER, Helsinki.

Bouët, A., S. Mishra, and D. Roy. 2008. "Does Africa Trade Less than It Should, and If So, Why? The Role of Market Access and Domestic Factors." IFPRI Discussion Paper 770, IFPRI, Washington, DC.

Bouët, A., L. Cosnard, and D. Laborde. 2017. "Measuring Trade Integration in Africa." Journal of Economic Integration 32 (4): 937-977.

Bouët, A., and Odjo, S. P., eds. 2019. Africa Agriculture Trade Monitor 2019. Washington, DC: IFPRI.

CEPII. 2011. "What Benefits From Completing the Single Market?", Lettre du CEPII no. 316, Centre d'Etudes Prospectives et d'Informations Internationales.

Das Nair, R. 2018. "The Internationalisation of Supermarkets and the Nature of Competitive Rivalry in Retailing in Southern Africa." Development Southern Africa 35 (3): 315-333.

du Plessis, S., B. Smit, and C. McCarthy. 2000. International Economics. Johannesburg: Heinemann.

Fadeyi, O. A., T. Y. Bahta, A. A. Ogundeji, and B. J. Willemse. 2014. "Impacts of the SADC Free Trade Agreement on South African Agricultural Trade." Outlook on Agriculture 43 (1): 53-59. 
Fall, F., and B. Gasealahwe. 2017. "Deepening regional integration within the Southern African development community." OECD Economics Department Working Paper 1450, OECD Publishing, Paris.

FAO (Food and Agriculture Organization). 2016. FAOSTAT. http://faostat.fao.org/default.aspx

Hummels, D., and P. J. Klenow. 2005. "The Variety and Quality of a Nation's Exports." American Economic Review 95 (3): 704-723.

Hwang, K. D. 2007. "The Historical Evolution of SADC(C) and Regionalism in Southern Africa." International Area Studies Review 10 (1): 56-72.

International Telecommunications Union. 2020. ICT database. Geneva, Switzerland.

ITC (International Trade Centre). 2017, 2020. Trade Map. http://www.trademap.org.

Kalaba, M. 2014. "The Impact of Non-Tariff Measures on SADC Agricultural Trade." PhD thesis, University of Pretoria, South Africa.

Kalaba, M., J. Kirsten, and T. Sacolo. 2016. "Non-tariff Measures Affecting Agricultural Trade in SADC." Agrekon 55 (4): 377-410.

Mmaduabuchukwu, M. 2013. "Service Trade and Non-oil Export in Nigeria." Russian Journal of Agricultural and Socio-Economic Sciences 13 (1): 18-25.

Ngalawa, H. P. 2014. "The Anatomy of the Southern African Customs Union: Structure and Revenue Volatility." International Business \& Economics Research Journal 13 (1): 145-156.

Novy, D. 2012. "Gravity Redux: Measuring International Trade Costs with Panel Data." CEP Discussion Paper 1114, Centre for Economic Performance, London School of Economics and Political Science, London.

OECD. 2016. "Agriculture in Sub-Saharan Africa: Prospects and Challenges for the Next Decade." In OECD-FAO Agricultural Outlook 2016-2025, OECD Publishing, OECD/FAO, Paris.

Oluwatoba, A. F., T. Y. Bahta, A. A. Ogundeji, and B. J. Willemse. 2014. "Impacts of the SADC Free Trade Agreement on South African Agricultural Trade." Outlook on Agriculture 43 (1): 5359.

Onoja, A. O., A. I. Achike, and T. B. Ajibade. 2017. "Econometric Analysis of Short-Run and Long-Run Determinants of Agricultural Value Addition in Africa." Agrosearch 17 (1): 26-43.

Peters-Berries, C. 2010. Regional Integration in Southern Africa: A Guidebook. Bonn: Internationale Weiterbildung und Entwicklung.

SACU (Southern African Customs Union). 2017. Annual Report. Windhoek.

SACU. 2019. SADC RTGS Newsletter Issue 1. Pretoria: South African Reserve Bank.

SADC (Southern African Development Community). 2012. "Regional Indicative Strategy Development Plan." Gaborone, Botswana.

SADC. 2019. SADC Regional Infrastructure Development-Short Term Action Assessment 2019. SADC, SARDC.

SADC. 2020. Accessed May 29, 2020. https://www.sadc.int/documents-publications/keystrategies/. 
Sandrey, R., W. Viljoen, and Y. Potelwa. 2018. "Intra-African Agriculture Trade: An Overview." In Agriculture and the African Continental Free Trade Area. Stellenbosch: Tralac.

Shepherd, B. 2016. "Infrastructure, Trade Facilitation and Network Connectivity in Sub Saharan Africa." Journal of African Trade 3: 1-22.

Tralac. 2018. One Stop Border Post Sourcebook, 2nd Edition.

UNECA (United Nations Economic Commission for Africa). 2018. African Continental Free Trade Area: Towards the Finalization of Modalities on Goods. Addis Ababa.

World Bank. 2013. Africa Development Indicators 2012/2013. Washington, DC.

World Bank. 2016, 2017, 2018, 2019. Doing Business Report. Washington, DC.

World Bank. 2020a. World Bank Enterprises surveys. Washington, DC.

World Bank. 2020b. World Development Report 2020: Trading for Development in the Age of Global Value Chains. Washington, DC.

World Bank. 2020c. World Development Indicators database. Washington, DC.

World Economic Forum. 2012, 2014, 2016, 2017, 2018, 2019. Global Competitiveness database.

Cologny-Geneva. 


\section{Summary and Conclusions}

The 2020 AATM presented an overview of trade in agriculture products in Africa and highlighted the main impediments that affect intra- and extra-African trade. This final chapter summarizes the major findings of this report and offers some policy recommendations for improving agricultural exports performance, especially in the context of the unprecedented uncertainty the world is facing with the COVID-19 pandemic.

Chapter 1 provided a general overview of African agricultural exports, regional integration, and informal trade in Africa. It also indicated the various impacts of the pandemic in terms of food security and production. While global production levels of essential food commodities in 2020 are satisfactory, there are various channels through which the pandemic negatively affects the continent. Among these are the decline in remittances; the loss of tourism receipts with the total or partial restrictions imposed on travelers; the potential decrease in international aid due to the recession in advanced economies; and the historic decrease in prices of major commodities (which represent a significant amount of Africa's exports).

The main trends in agricultural trade were presented in Chapter 2, which analyzed both trade flows and trade policies. Generally speaking, African agriculture is characterized by low productivity when compared to other developing regions, and African agricultural exports account for only a small share of the world's exports. A closer look at the destination of trade flows shows that African countries export chiefly to traditional markets (such as the United States and Europe) but have also diversified their exports to some emerging markets. In terms of export composition, Africa's exports are still relatively concentrated in a few products; the top 10 export products represent 39 percent of Africa's agricultural exports (cocoa beans, cashew nuts, tobacco, coffee, oranges, cotton, sesame seeds, black tea, cocoa paste, and fresh grapes). In regards to trade policies, although tariffs are low, nontariff measures (NTMs) substantially hinder African trade. Among these NTMs, sanitary and phytosanitary standards, administrative barriers, and domestic support in major exporters are most significant.

Chapter 3 focused on intra-African trade integration. SADC and COMESA are notably the largest players, followed by ECOWAS, then AMU and ECCAS. At the country level, South Africa remained the predominant trader, with exports amounting to nearly a third of all intra-Africa formal exports, and imports accounting for roughly a tenth of all agricultural goods. It is crucial to note that current export patterns within the different African regions are sufficiently dissimilar to suggest there is room to expand intraregional trade within the continent. To achieve this, more coordinated efforts must be deployed to promote a more integrated market and reduce the negative effects of NTMs and behind-the-border barriers.

In the 2019 AATM, Chapter 4 examined the evolution of competitiveness in key commodity value chains in Africa, showing that Africa's comparative advantage in agriculture has strengthened in very recent years. This year's Chapter 4 focused on the lack of competitiveness of African value chains that are fundamental to food security: cereals and cassava, sugar and related products, and vegetable oils. The chapter first examined indicators of trade and comparative advantage at different levels, continental or by country, by degree of processing, and by crop at the source of this value chain; it then assessed the degree of distortion introduced by the policies of large (rich and emerging) countries. On the one hand, the chapter found that while the African continent has a significant comparative disadvantage in these three value chains, some African countries may have a comparative advantage at certain stages of processing in these value chains. But too often the advantage is concentrated at the unprocessed stage. On the other hand, it showed that 
while the policies of the European Union, the United States, China, and India are highly distorting for certain products or at certain stages of processing, most African countries still suffer from structural weaknesses in their supply capacities in these value chains: poor access to the most recent technologies; insufficient infrastructure in transport, customs, telecommunications, and energy; and insufficient labor skills.

Informal cross-border trade (ICBT) was the subject of Chapter 5. In Africa, ICBT is fundamental in terms of income generation, food security, and the inclusion of women in economic life. The chapter began by clearly defining this economic activity, as different definitions of the term are used. Then it identified the causes of ICBT, which include historical, cultural, and economic factors. It is the product not only of the largely arbitrary formation of African states, but also of the many prevailing barriers to formal trade. Two initiatives to measure ICBT were presented: those implemented by CILSS $^{1}$ in West Africa and by UBoS and BoU ${ }^{2}$ in Uganda. Indeed, the lack of accuracy in African agricultural trade statistics is an important issue often highlighted in the 2020 AATM, as in previous editions.

Chapter 6 looked at regional integration experiences in Southern Africa, focusing on SADC. Trade integration in this part of Africa has a long history: SACU is the oldest customs union still in existence today. The birth of SADC was the result of the political will of nine countries in the region to reduce their dependence on apartheid-era South Africa. SADC has since accepted new members and now comprises 16 countries. However, the initial political will has not sparked a real economic evolution: the free trade area has not been transformed into a customs union; NTMs affecting intraregional trade are still numerous; and customs, electricity, transport, and telecommunications infrastructure have not significantly improved. Current trade among the SADC countries reveals a number of weaknesses that have not been resolved in recent years, most notably the overly large share of primary goods exports, with a high concentration in a few products (tobacco, corn, sugar, live animals) that are similar in all countries. Moreover, participation of Southern African countries in global value chains is low: only South Africa exports and imports intermediate goods in a significant way. The authors concluded by pointing to the need for genuine political will to emerge to advance trade integration in the region.

At the beginning of July 2020, the main concern of Africans is the COVID-19 crisis and its potential impact on food security on the continent. A large part of Africa's food supply is provided through "transitional chains," where it is very difficult to organize social distancing. Many African countries have banned people from crossing borders but accept the crossing of freight with tighter health controls. This restriction will slow, if not stop, ICBT and slow down recorded trade. The introduction of curfews also increases the loss and waste of food. Add to this crop losses caused by locusts, mainly in East Africa, and the potential impact on food security is worrying.

In view of this crisis, strengthening regional integration in Africa is therefore increasingly important, particularly to improve food security. Increasing integration will require lowering or even removing tariff barriers and NTMs and improving transport, customs, telecommunications, and electricity infrastructure. While many African regional agreements, such as SADC, are disappointing in this regard, the African Continental Free Trade Area is today the focus of hope. Due to the health situation, its launch has been postponed until January 1, 2021. It is hoped that the current crisis will increase the scope of this agreement and strengthen the motivation of African governments to implement it effectively.

1 Comité Permanent Inter-état de Lutte contre la Sècheresse au Sahel.

2 Uganda Bureau of Statistics and Bank of Uganda. 
